\title{
On the influence of sewage pollution on inshore benthic communities in the South of Kiel Bay
}

\author{
Part 2. Quantitative studies on community structure
}

\author{
K. ANGER \\ Biologische Anstalt Helgoland (Meeresstation); \\ Helgoland, Federal Republic of Germany
}

KURZFASSUNG: Zum Einfluß kommunaler Abwässer auf küstennahe benthische Gemeinschaften in der südlichen Kieler Bucht. Teil 2. Quantitative Untersuchungen zur Struktur der Gemeinschaften. Innerhalb eines Verschmutzungsgradienten von 2000 m Radius um die Einleitungsstelle kommunaler Abwässer bei Bülk (westliche Ostsee) konnten auf Sandböden drei Assoziationen gefunden werden. Sie sind charakterisiert durch: (a) den Polychaeten Capitella capitata und Oligochaeten (50-100 m Entfernung von der Einleitungsstelle der Abwässer); (b) den Polychaeten Pygospio elegans (200-ca. $700 \mathrm{~m}$ ) und (c) den Amphipoden Bathyporeia sarsi $(>700 \mathrm{~m})$. Die Assoziationsgrenzen sind verschwommen, es liegt ein Kontinuum vor. Der Einfluß biogener Substratstrukturen wird im schwächer verschmuzten Bereich deutlicher. Hier können Assoziationen klar abgegrenzt werden. Die Kombination der Lebensformtypen, Artenzahl, Diversität und andere Eigenschaften der Gemeinschaften hängen in charakteristischer Weise von der räumlichen Heterogenität des Substrates ab. Sie werden ebenfalls stark vom Verschmutzungsgrad beeinflußt. Die küstennahe benthische Makrofauna liefert einen wichtigen Beitrag zur Selbstreinigung des ganzen Okosystems, indem es partikuläre organische Substanzen zu nutzbarer Fischnahrung umformt. Abundanz und Biomasse werden dabei vervielfacht. Dieser Vorgang bringt zusätzlich zum Eutrophierungsproblem die Gefahr der Anreicherung von Giftstoffen mit sich. Komplexere Systeme (z. B. Miesmuschelbänke) sind besser auf solche Faktoren eingestellt, die unmittelbar die Aquität der Gemeinschaft beeinflussen. Der ökologische Puffer besteht aus vielen spezialisierten Konkurrenten und Räubern. Niedrig diverse Systeme (z. B. Sandböden) reagieren mit hohen Amplituden auf Störungen dieses Typs. Zusammensetzung, Aquität, Artenreichtum, Abundanz und Biomasse tierischer Gemeinschaften sind brauchbare Parameter einer ökologischen Methode zur Früherkennung von Umweltbelastungen.

\section{INTRODUCTION}

For several decades, particularly in the last few years, an increasing endangering of the Baltic Sea through spreading of abiotic areas characterized by oxygen insufficiency and hydrogen sulfide has been registered (Fonselius, 1962, 67, 69; IcEs report, 1970). The main causes are probably a steady increase of salinity (Fonselius, 1969) together with temperature (KullenberG, 1970). Pollution caused by all countries bordering on the Baltic Sea has also contributed to the problem. 
In this situation facts and models are needed concerning the reactions of different Baltic Sea areas and of their ecosystem fractions on all kinds of disturbances, whether of natural or human origin. This paper deals with an inshore benthic subsystem partially polluted by sewage, which was described in a preliminary report after a half year pilot study (ANGER, 1975). Particular attention is paid to seasonal and pollutioninfluenced changes of the community structure, on production in different levels of benthic eutrophication (in the widest sense), and to the role of the substrate type. The relationships between the system's "spatial heterogeneity", "physical stability", "complexity" (measured as diversity), and "biotic constancy" were observed. The question is raised whether an ecological structure analysis as performed here is an appropriate method of measuring environmental stress.

\section{THE INVESTIGATION AREA}

In the South of Kiel Bay near Bülk about $50,000 \mathrm{~m}^{3}$ of untreated sewage was pumped every day into the Baltic Sea. The investigation area was thoroughly described by Horstmann (1972), Hubrich (1972) and Anger (1975). The bacterial contamination due to the sewage pollution was investigated by Gramm (1936), RHEINHEIMER (1966, 67), GäRTNER (1969) and SADJEDI (1971). Hydrographical studies were performed in Kiel Bay by Wattenberg (1949), KändLer $(1952,59,60)$, OHL (1959), KRUG (1963) and other workers. HoRsTMANN (1972) elaborated data on plankton and discussed older literature. A model of the dispersion of the pollutants was calculated by Hubrich (1972). Some information on phosphate, silicate, seston and other pollution parameters is given by Horstmann (1972) and ANGER (1975).

Table 1

Quality and composition of the sewage discharged at Bülk

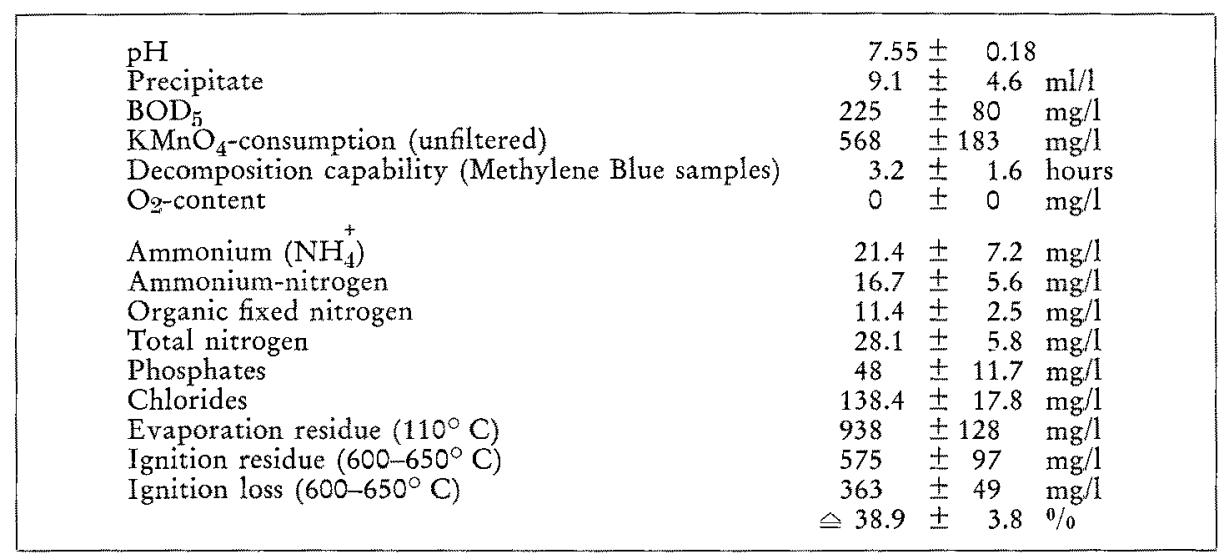

Table 1 presents additional data on the composition and some other attributes of the sewage. It consisted mainly of organic particles; poisonous substances do not play 
any apparent role. The sampling cruises concentrated on the $3 \mathrm{~m}$ depth line. Here there is a medium fine sand with a median grain size of $250-300 \mu$, which had to be regarded as "less well sorted" (sorting coefficient: 50-200 p). The ignition loss showed significantly higher values up to more than $7 \%$ in the heavily polluted zone, but just a slight increase in the transition area $(200-500 \mathrm{~m}$ distance from the sewage outlet) and a normal level (below $1 \%$ ) in all other stations. For further details of the sediment quality and its meiobenthos see ANGER \& SCHEIBEL (in press).

In contrast to the grain size some macroorganisms had a high influence on the benthic populations: Mussel beds (Mytilus edulis) and eel-grass (Zostera marina) altered the substrate conditions completely and therefore they were regarded as dominant factors in this study.

The oxygen saturation was measured in the near bottom water by means of the TO-probe described by GrAsHoff (1969). Since all values averaged about 100 \%, oxygen was considered to be a less important factor for the macrobenthos. The salinity in the investigation area normally fluctuates between 13 and $18 \%$. It has no importance in this case, as neither horizontal nor vertical gradients could be observed. The water temperature was recorded every day and related to spawning periods of benthic animals (for details see ANGER, in press).

Thus changes in the composition of faunal assemblages can be caused by seasonal temperature fluctuations, differing concentrations of sedimenting organic particles, or dominant substrates. Other factors are less significant.

\section{MATERIALS AND METHODS}

Nine inshore stations were investigated at constant distances from the sewage outlet: $50,100,200,300,500,700,1000,1500,2000 \mathrm{~m}$. These distances are used as measures for the degree of sewage pollution; for data on the dilution rates see HorsTmANN (1972), Hubrich (1972) and ANger (1975). From August 1971 until September 1972129 macrofauna samples were taken by means of a $0.1 \mathrm{~m}^{2}$ van Veen grab. In addition 28 samples collected in June and July 1971 from other stations were considered for some comparisons.

Each sample consisted of two parallel grabs and thus represented $0.2 \mathrm{~m}^{2}$. Its content was immediately strained through a sieve with $1 \mathrm{~mm}$ mesh size and preserved in a $4 \%$ formaline solution. In order to investigate young bottom stages of macrobenthic animals during the year simultaneous meiofauna samples were taken at each pure sand station (cf. ANGER \& SCHEIBEL, in press). The material was sorted and identified under a stereo microscope in the laboratory. The biomass was determined as dry weight of samples dried at $100^{\circ} \mathrm{C}$ to constant weight. For the calculation of diversity indices a PDP 10 computer belonging to Kiel University was used. 


\section{RESULTS}

\section{General Remarks}

Table 2 gives a rough idea of the macrobenthic colonization of the whole investigation area. The 34 most common species are ranked according to the number of station samples in which they occurred. The percentage frequency or presence $(P)$ and mean dominance $(=$ individual percentage of a certain species $=\overline{\mathrm{D}}$ ) is indicated for the main substrate types, sand $(S)$, sea grass $(\mathrm{Sg})$ and mussel beds $(M)$. This allows the recognition of substrate preferences.

Table 2

List and rank of the most common species according to the number of stations (St.) they were found. Presence $(\mathrm{P})$ and mean dominance $(\mathrm{D})$ on sand $(\mathrm{S})$ seagrass $(\mathrm{Sg})$, and mussel beds $(\mathrm{M})$

\begin{tabular}{|c|c|c|c|c|c|c|c|}
\hline \multirow{2}{*}{ Species } & \multicolumn{4}{|c|}{$\mathrm{P} \%$} & \multicolumn{3}{|c|}{$\overline{\mathrm{D}} \%$} \\
\hline & St. & $S$ & $\mathrm{Sg}$ & M & $S$ & $\mathrm{Sg}$ & M \\
\hline Capitella capitata & 146 & 89.5 & 95.2 & 100 & 19.4 & 1.6 & 9.8 \\
\hline Macoma baltica & 145 & 87.7 & 100 & 100 & 3.6 & 2.4 & 0.8 \\
\hline Hydrobia wlode & 141 & 88.9 & 96.2 & 89.5 & 6.0 & 6.0 & 2.4 \\
\hline Mytilus edulis & 140 & 84.8 & 96.2 & 100 & 2.4 & 5.7 & 29.2 \\
\hline Pygospio elegans & 136 & 91.2 & 100 & 100 & 26.1 & 42.5 & 8.3 \\
\hline Nereis diversicolor & 128 & 84.2 & 66.7 & 81.3 & 2.9 & 0.5 & 0.6 \\
\hline Mya arenaria & 126 & 73.7 & 88.5 & 94.7 & 4.2 & 5.8 & 2.8 \\
\hline Eteone longa & 104 & 66.7 & 100 & 63.2 & 0.7 & 1.1 & 0.4 \\
\hline Coropbium insidiosum & 100 & 28.2 & 100 & 90.0 & 0.5 & 5.3 & 9.4 \\
\hline Gammarus salinus & 88 & 36.8 & 57.1 & 87.5 & 0.5 & 0.1 & 2.7 \\
\hline Anaitides mucosa & 84 & 45.6 & 95.2 & 62.5 & 0.2 & 0.6 & 0.1 \\
\hline Idotea baltica & 83 & 32.3 & 96.2 & 94.7 & - & 1.9 & 1.1 \\
\hline Microdeutopus gryllotalpa & 81 & 30.3 & 92.3 & 89.5 & 0.1 & 1.7 & 4.7 \\
\hline Cardium lamarcki & 77 & 40.6 & 87.0 & 55.6 & 5.6 & 1.2 & 0.1 \\
\hline Scoloplos armiger & 75 & 54.4 & 85.7 & 56.3 & 0.9 & 3.2 & 1.8 \\
\hline Arenicola marina & 73 & 43.9 & 61.9 & 56.3 & 0.5 & 0.2 & 0.4 \\
\hline Littorina littorea & 72 & 39.1 & 69.6 & 77.8 & 0.2 & 0.4 & 0.5 \\
\hline Spio filicornis & 69 & 71.9 & 38.1 & 18.8 & 4.4 & 0.1 & 0.3 \\
\hline Batbyporeia sarsi & 69 & 87.0 & 27.8 & 28.6 & 10.0 & 0.1 & 0.7 \\
\hline Polydora ciliata & 68 & 22.2 & 84.6 & 89.5 & 0.2 & 2.7 & 5.5 \\
\hline Polydora ligni & 64 & 24.6 & 57.1 & 68.8 & 0.1 & 0.5 & 1.7 \\
\hline Crangon crangon & 51 & 42.1 & 66.7 & 25.0 & 0.3 & 0.1 & 一 \\
\hline Asterias rubens & 49 & 11.6 & 82.6 & 83.3 & - & 0.6 & 0.6 \\
\hline Gammarus oceanicus & 48 & 10.1 & 65.4 & 73.7 & - & 0.2 & 0.8 \\
\hline Harmotboe impar & 44 & 15.8 & 38.1 & 100 & - & - & 0.6 \\
\hline Nereis succinea & 41 & 13.1 & 42.3 & 78.9 & 0.1 & 0.1 & 0.7 \\
\hline Calliopius laeviusculus & 37 & 11.1 & 50.0 & 42.1 & 一 & 0.1 & 0.1 \\
\hline Fabricia sabella & 35 & 8.8 & 61.9 & 56.3 & - & 5.0 & 0.3 \\
\hline Lacuna divaricata & 34 & 8.1 & 61.5 & 52,6 & - & 0.3 & 0.2 \\
\hline Balanus crenatus & 34 & 8.1 & 23.1 & 78.9 & 一 & - & 1.3 \\
\hline Pholoe minuta & 33 & 1.8 & 57.1 & 68.8 & - & 0.2 & 0.2 \\
\hline Jaera albifrons & 33 & 10.1 & 43.5 & 72.2 & - & 0.1 & 0.2 \\
\hline Carcinus maenas & 32 & 10.5 & 57.1 & 75.0 & - & 0.1 & 0.2 \\
\hline Rissoa inconspicua & 25 & 7.1 & 42.3 & 42.1 & 一 & 0.1 & 0.1 \\
\hline
\end{tabular}




\section{Pollution and seasonal infuenced changes}

The annual mean biomass $(\bar{B})^{*}$ and abundance $(\bar{A})$ of the entire macrofauna is increased on average by a factor of 10 in the semipolluted area as compared with unaffected stations (Fig. 1).

Three zones can be distinguished within the investigation area: Zone I: $50-200 \mathrm{~m}$ distance from the outlet, zone II: $300-700 \mathrm{~m}$ distance from the outlet, zone III: 1000-2000 $\mathrm{m}$ distance from the outlet.

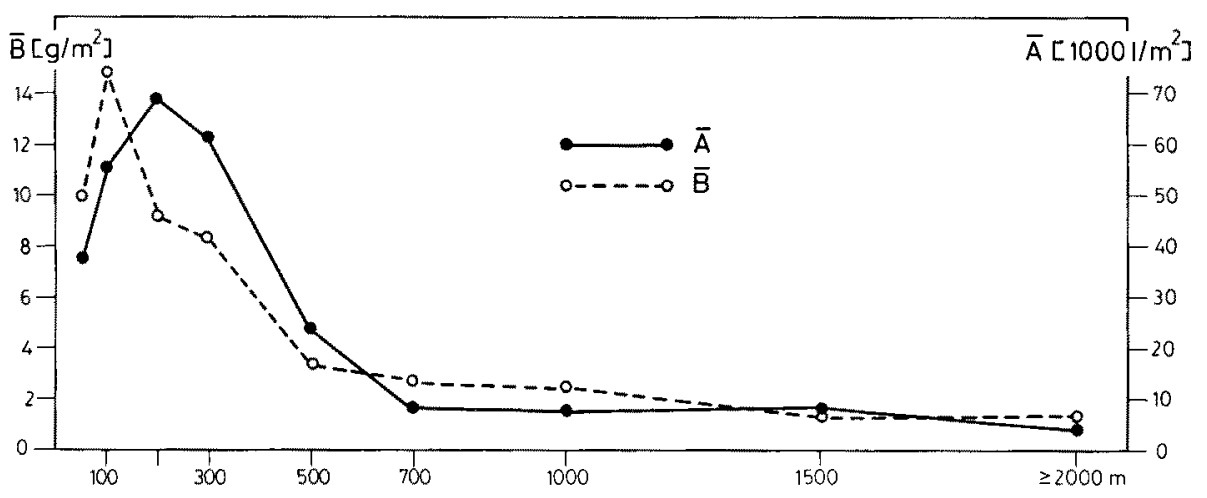

Fig. 1: Mean abundance $(\bar{A})$ and biomass $(\bar{B})$ within the pollution gradient

When these zones are compared in terms of an annual cycle of abundance and biomass (Fig. 2) and of the percentage of major groups (Fig. 3), significant differences are apparent: Polychaetes, which are nearly always dominant (mainly Capitella capitata), and oligochaetes both increase their individual numbers by high propagation rates in zone I during July.

In the less polluted subareas II and III the same picture appears somewhat later due to settling of mulluscan larvae (Mya arenaria, Macoma baltica, Cardium lamarcki, Hydrobia ulvae), while at the same time in zone $I$ the young annelid populations are greatly reduced. In autumn in the sewage affected zones $I$ and II a new population rise takes place, this is attributed to the polychaete Pygospio elegans. In the nearly unaffected part III the relative importance of the amphipod Bathyporeia sarsi increases at the same time. After the general decrease in population density at beginning of winter a new peak occurs in February in zones II and III. It can be attributed partly to Pygospio elegans (II), and partly to several amphipod and polychaete species (III).

In zone III the abundance values remain constantly low until July, while the corresponding biomass rises. During this time the dominating worms Pygospio elegans

* To avoid a masking of trends by irregularly occurring animals with heavy calcareous bodies, all representatives of Mollusca, Echinodermata, Cirripedia and Carcinus maenas were excluded from biomass calculations. 
and Capitella capitata produce high population densities again. The culmination of the polychaete propagation phase is finally reached in July.

At this time Capitella capitata clearly dominates zone I. Pygospio elegans which is also very abundant here, dominates zone II even more conspicuously.

In summer 1972 the biological composition of the three zones was remarkably similar. This fact can be interpreted as follows: Simultaneously with the annelids men-

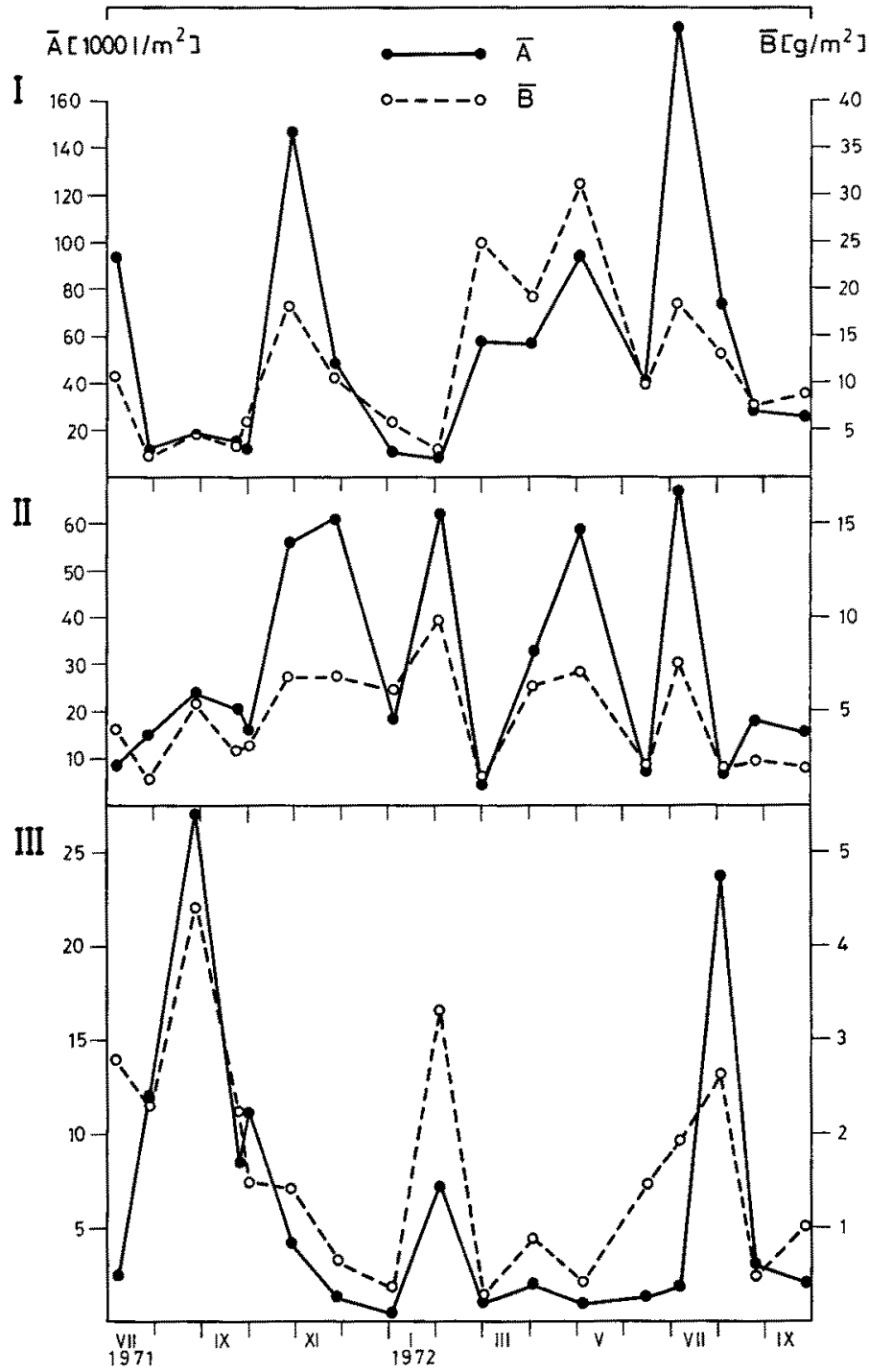

Fig. 2: Mean abundance $(\overline{\mathrm{A}})$ and biomass $(\bar{B})$ during the year $(I=50-200 \mathrm{~m}, I I=300-700 \mathrm{~m}$, III $=1000-2000 \mathrm{~m}$ distance from the outlet) 


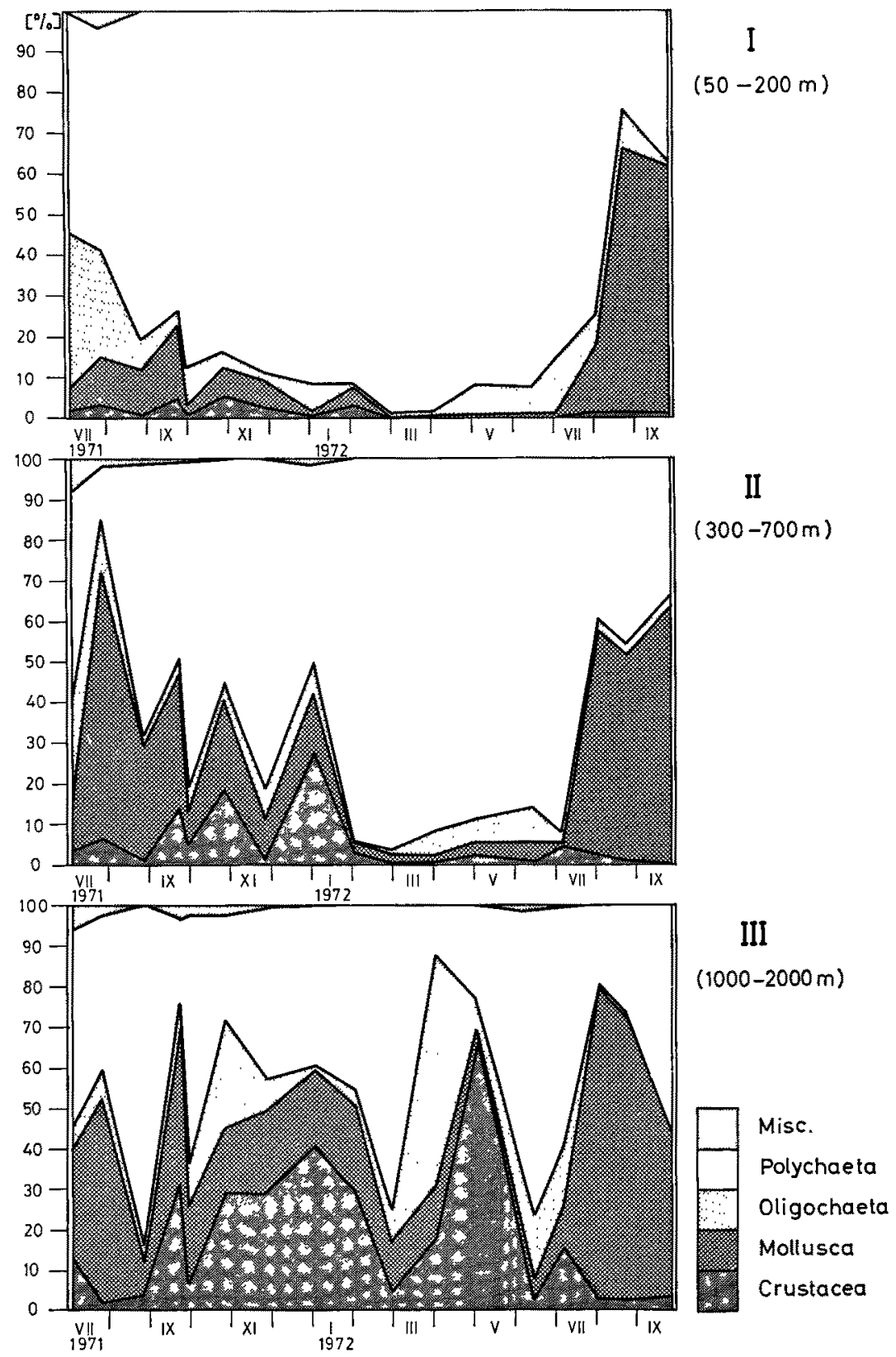

Fig. 3: Percentage of the most important macrofauna groups during the year 
tioned above, the predator Nereis diversicolor also had an unusually strong reproductive phase, when the mechanical sewage treatment was started. Thus a considerable abatement of food supply and contemporary predation by normally omnivorous animals reduced the population densities of the typical detritus feeding polychaetes Capitella capitata and Pygospio elegans. During this period masses of molluscan larvae settled on the sandy bottom and appeared as additional competitors.

It must be assumed that later the faunal assemblages of zones $I$ and II were altered remarkably, becoming more and more similar to those of zone III. This development was not investigated.

\section{Interspecific association}

Community analysis was introduced by evaluating species groups which are connected by a high degree of interspecific association. For this purpose every possible species pair was examined for its distribution affinity using the index proposed by JACCARD (1912) for phytosociological studies.

It is calculated by the formula

$$
J=c /(a+b-c)
$$

where $\mathrm{a}=$ number of stations (samples) containing species $\mathrm{A}, \mathrm{b}=$ number of stations (samples) containing species $\mathrm{B}, \mathrm{c}=$ number of stations (samples) containing species $\mathrm{A}$ and $B$ together.

After transforming to percentage values ("percentage affinity") the matrix was arranged in a Trellis diagram. It was started with the species showing the highest number of index values over 50 , followed by the species with the highest affinity to the first one. The succeeding rank resulted from the respective highest affinities to the already existing group. The whole procedure was carried out separately for the regions $50-500 \mathrm{~m}$ and $700-2000 \mathrm{~m}$ distance from the sewage pipeline.

Figure 4 shows the association pattern in the rather unaffected zone. The most conspicuous group consists of the commonest species inhabiting sand flats and eel grass meadows (cf. Table 2): Mytilus edulis, Macoma baltica, Pygospio elegans, Hydrobia ulvae, Eteone longa, Capitella capitata, Mya arenaria, Nereis diversicolor, Cardium lamarcki, Scoloplos armiger, Arenicola marina, Spio filicornis, Bathyporeia sarsi.

A second accumulation of high indices appears in the left upper corner of the diagram. It is composed of animals living in phytal and other growth: Corophium insidiosum, Idotea baltica, Asterias rubens, Littorina littorea, Polydora ciliata, Anaitides mucosa, Harmothoe impar, Polydora ligni, Pholoe minuta, Fabricia sabella, Gammarus oceanicus, Jaera albifrons, Gammarus salinus, Lacuna divaricata.

The rest of the species are too sparse to reach high Jaccard-values. Crangon crangon has a conspicuous affinity to the first group, the other species tend to the second one: Nereis succinea, Rissoa inconspicua, Carcinus maenas, Calliopius laeviusculus, Balanus crenatus.

In general, a strong influence of biotic substrate structures on macrofaunal association is visible. 
In the polluted zone $(50-500 \mathrm{~m}$ ) the affinity pattern is quite different (Fig. 5). The seven commonest macrobenthic species are extremely strongly associated. All are more or less favoured by organic pollution and under well defined preconditions they can

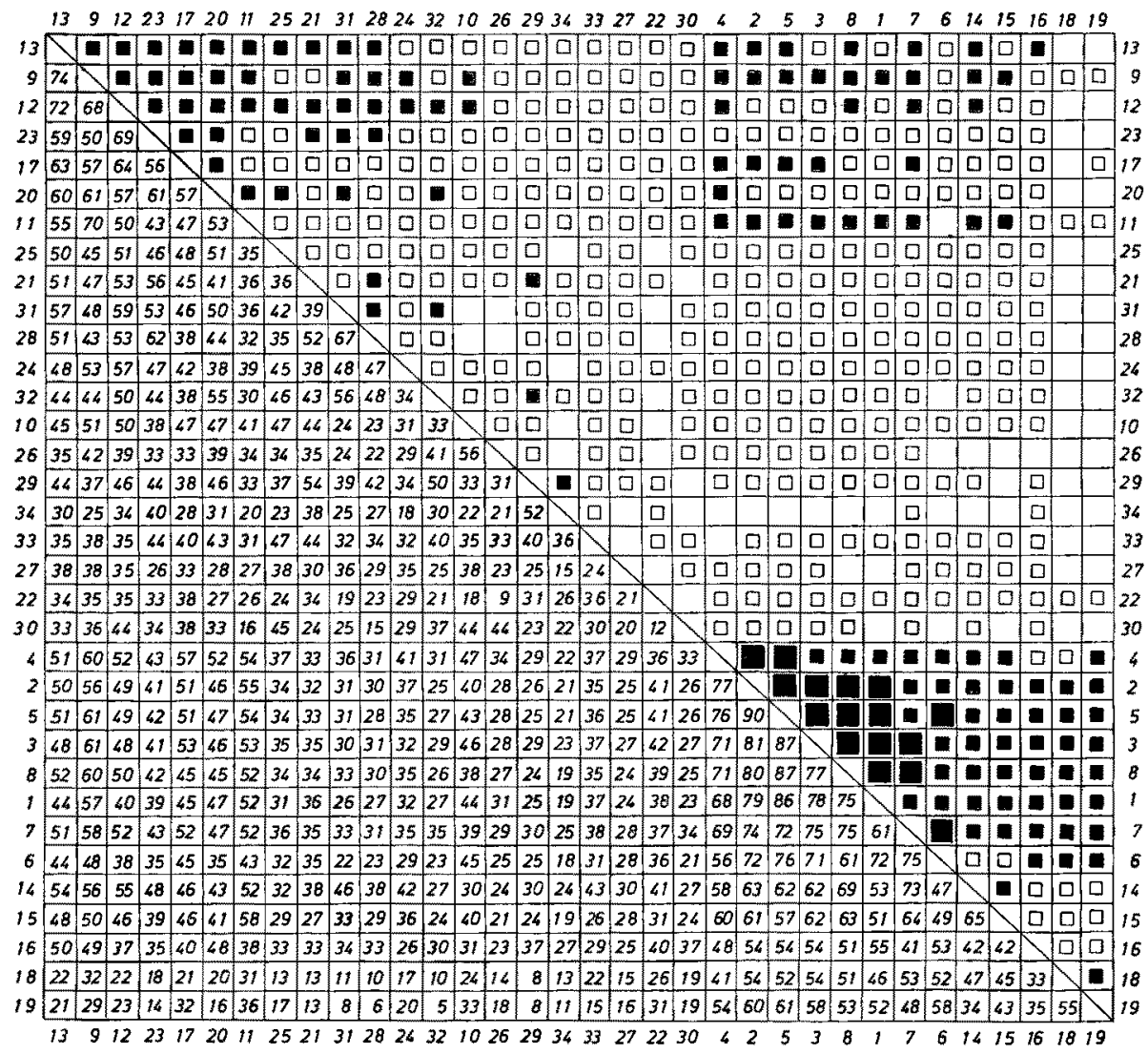

Fig. 4: Interspecific association, expressed as percentage affinity (JACCARD-index $\times 100$ ).

Stations from 700 to $2000 \mathrm{~m}$ distance from the outlet. For numbers of species see Table 2

have indicator quality: Pygospio elegans, Mya arenaria, Macoma baltica, Hydrobia ulvae, Nereis diversicolor, Mytilus edulis, Capitella capitata.

Seven euryoeceous growth dwellers with some indicator value show a high affinity to this group and complete it to a typical recurrent "indicator association" for organic pollution: Microdeutopus gryllotalpa, Corophium insidiosum, Anaitides mucosa, Idotea baltica, Gammarus salinus, Eteone longa, Polydora ligni.

A further group is made up of some species with only weak affinity to the stricter indicator group, but strong relationship to the last mentioned seven species: Cardium lamarcki, Polydora ciliata, Scoloplos armiger, Littorina littorea, Gammarus oceanicus, Arenicola marina, Asterias rubens, Nereis succinea, Crangon crangon, Harmotboe impar, Spio filicornis, Batbyporeia sarsi, Calliopius laeviusculus. 
The rarest species almost never occur in the polluted zone together with the indicators, but show mutually a higher affinity: Fabricia sabella, Lacuna divaricata, Jaera albifrons, Balanus crenatus, Pboloe minuta, Rissoa inconspicua, Carcinus meanas.

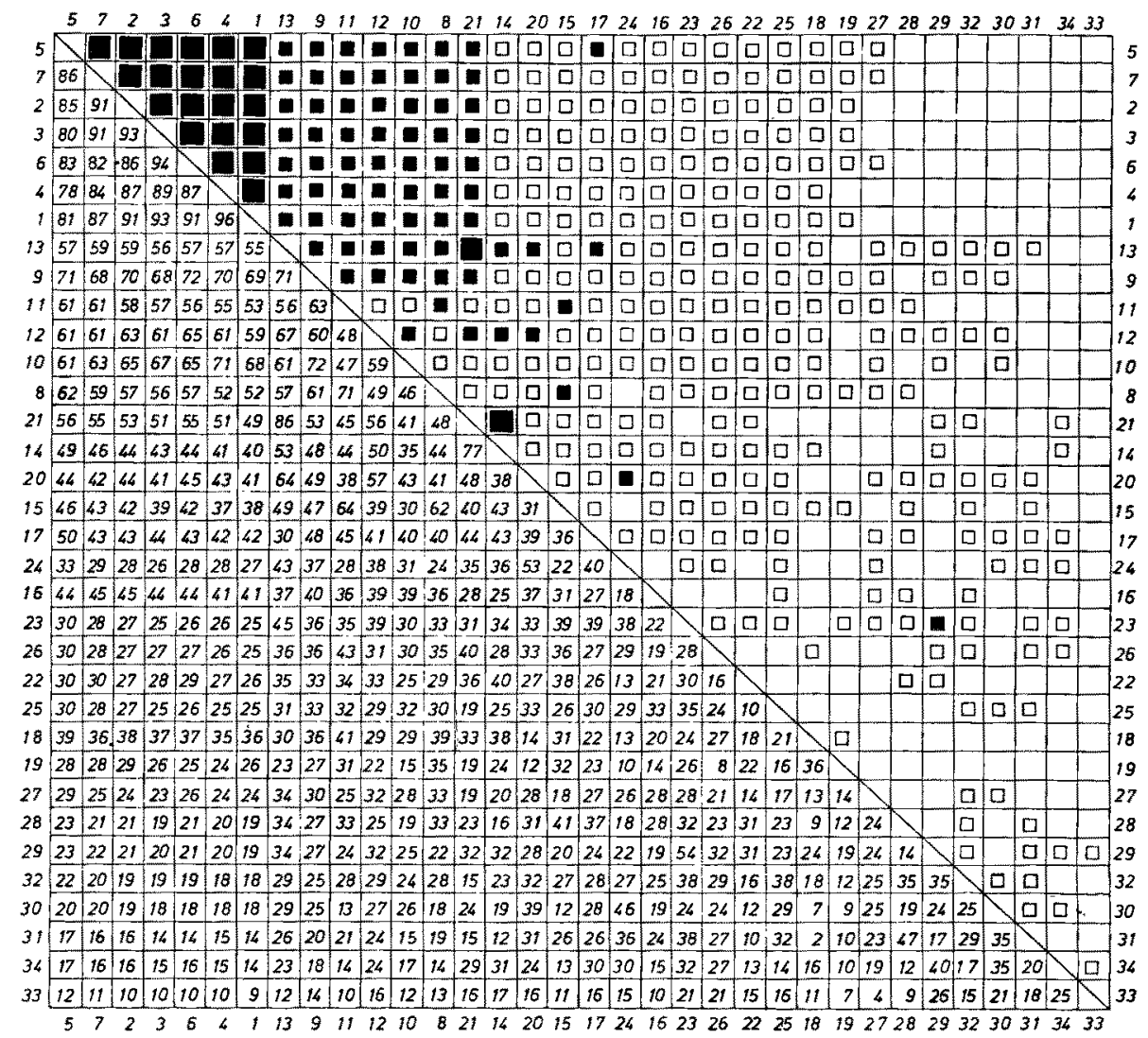

Fig. 5: Interspecific association (cf. Fig. 4). Stations from 50 to $500 \mathrm{~m}$ distance from the outlet

The pattern in the sewage affected reaches is primarily physically controlled. Species with a wide ecological range dominate clearly; biotic substrate properties do not have the critical importance they usually have.

\section{Substrate specifity}

To get a more refined picture from the ecological groupings one more approach is necessary. It is based on the more or less pronounced substrate preference of the single species. This can be expressed by relativating of population parameters as percentage frequency $(P)$ and mean abundance $(\bar{A})$ : 


$$
\mathrm{P}_{\mathrm{r}}=\frac{\mathrm{P} \times 100}{\mathrm{P}_{\Sigma}}(\%) \quad \overline{\mathrm{A}}_{\mathrm{r}}=\frac{\overline{\mathrm{A}} \times 100}{\overline{\mathrm{A}}_{\Sigma}}(\%)
$$

where $P_{r}, \bar{A}_{r}=$ relative presence, relative mean abundance; $P, \bar{A}=$ mean values, observed on a certain substrate; $P_{\Sigma}, \bar{A}_{\Sigma}=$ sum of the $P$ or $A$ on all three distinguished substrates together.

The $\mathrm{P}_{\Sigma}, \overline{\mathrm{A}}_{\Sigma}$ values correspond to $100 \%$. The $\mathrm{P}_{\mathrm{r}}$ and $\overline{\mathrm{A}}_{\mathrm{r}}$ values calculated in this way were arranged in triangular coordinate systems, since they always add up to $100 \%$ on all three substrates. To avoid overlapping influences of heavy pollution effects, all data from zone I were excluded from the calculations.

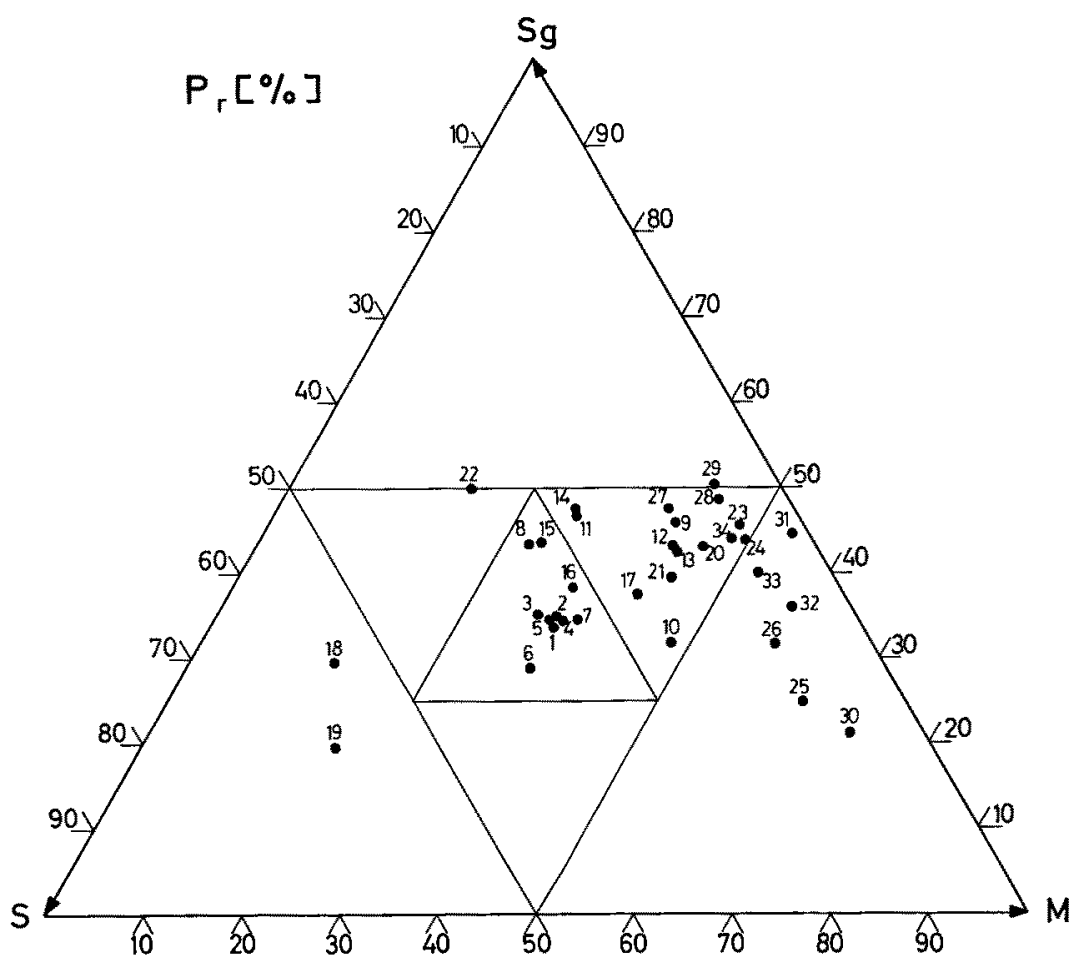

Fig. 6: Substrate specifity of the most common macrofauna species according to their relative frequency $\left(\mathrm{P}_{\mathrm{r}}\right)$. For abbreviations and numbers of species see Table 2

It must be stressed that the position of a species within the coordinate system is only an expression of its substrate specifity, not of its importance for the corresponding community.

The $P_{r}$ values (Fig. 6) make a group of eurytopous species visible, concentrated in the small central triangle. They are nearly identical with the "indicator association" identified by the Trellis diagram. They occur on the three substrates with about the 
same frequency. In the overlapping triangle between sea grass $(\mathrm{Sg})$ and mussel beds (M) there is a group of typical aufwuchs dwelling species, which are not restricted to one single substrate, but occur much less frequently on pure sand.

Crangon crangon tends to Zostera biotopes, but has also strong relationships with vegetation-free sand. Only a few species are already restricted to mussel beds by their frequency of occurrence, two (Spio filicornis and Batbyporeia sarsi) to sand bottoms, and just one (Lacuna divaricata) to eel grass.

According to Figure 7 the $\bar{A}_{r}$ values give a quite different pattern: No one species is completely indifferent regarding its quantitative distribution. Only a few species are nearly equally abundant on sand and Zostera meadows and only one is equally abun-

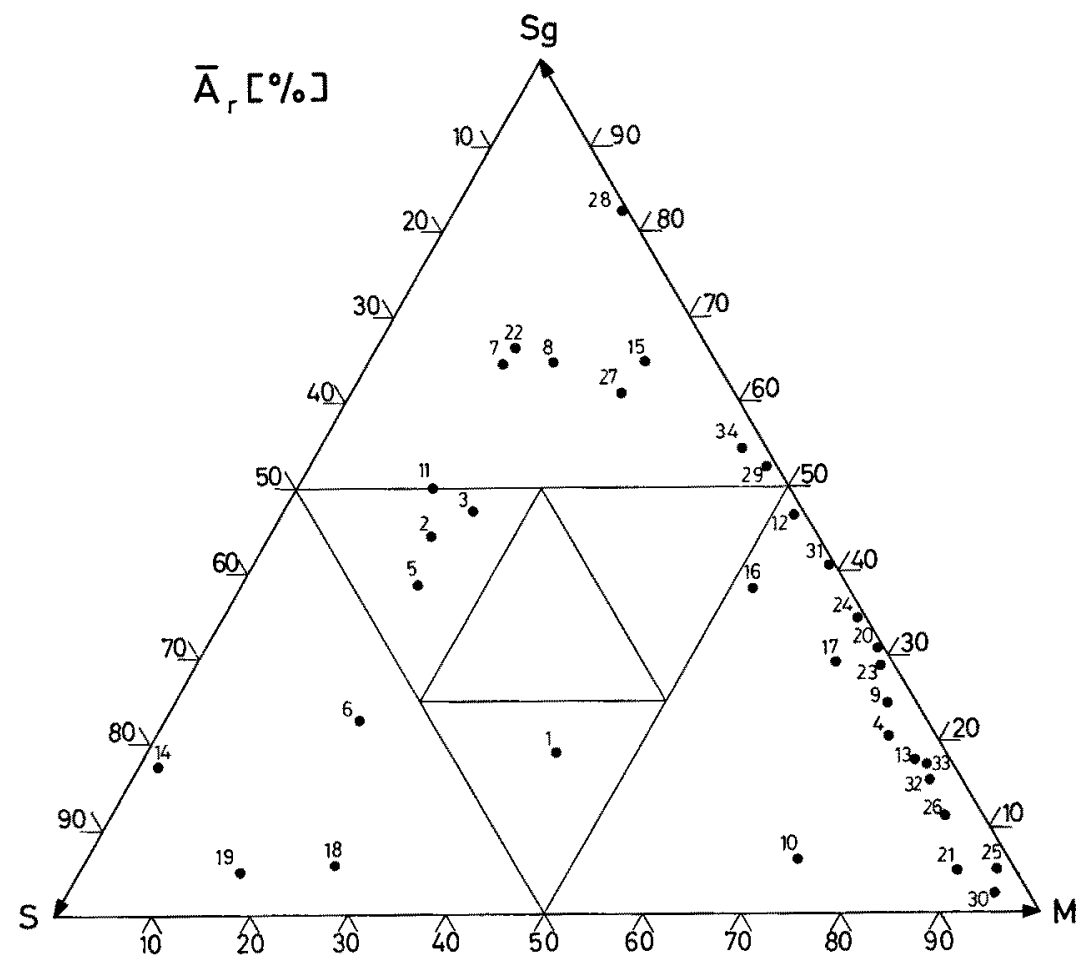

Fig. 7: Substrate specifity of the most common macrofauna species according to their relative mean abundance $\left(\overline{\mathrm{A}}_{\mathrm{r}}\right)$ (cf. Fig. 6)

dant on mussel beds and sand (Capitella capitata). All other macrobenthic species show a more or less clear quantitative preference for one single substrate ty pe.

In the following chapters the main benthic subsystems of the investigation area are biologically characterized by grouping species by substrate specifity and by ranking species according to their $\bar{A} P^{1 / 2-v a l u e s . ~ T h e s e ~ a r e ~ a n ~ e x p r e s s i o n ~ o f ~ t h e ~ q u a n t i t a t i v e ~}$ importance for a community (ERMAN \& Helm, 1971). 


\section{The sand bottom}

The majority of the sample material originates from more or less pure sand areas. Thus the most information comes from this simplest substrate type.

Table 3

Sand bottom community: Species grouped according to their substrate specifity. Explanations: $a=$ specific as regards both relative frequency and abundance; $b=$ only specific as regards relative abundance; $c=$ more frequent and $/$ or abundant on two substrates; $\mathrm{d}=$ indifferent as regards frequency, more abundant on other substrates

\begin{tabular}{|llll|}
\hline $\mathrm{a}$ & $\mathrm{b}$ & $\mathrm{c}$ & $\mathrm{d}$ \\
\hline Batbyporeia sarsi & Cardium lamarcki & Crangon crangon & Mytilus edulis \\
Spio filicornis & Nereis diversicolor & Pygospio elegans & Eteone longa \\
& & Capitella capitata & Mya arenaria \\
& & Macomabaltica & Scoloplos armiger \\
& & Hydrobia ulvae & Arenicola marina \\
& & Anaitides mucosa & \\
\hline
\end{tabular}

As can be established from Figures 6 and 7 only a few species are characteristic for this subsystem (group " $a$ " in Table 3 ). They can be supplemented by the highly specific, but sparsely occurring Pseudocuma longicorne (Cumacea) and Batbyporeia pilosa (Amphipoda).

A completely different rank can be set up regarding the quantitative importance (measured as $\overline{\mathrm{A}} \mathrm{P}^{1 / 2}$ ). Table 4 is completed by the systematic groups Oligochaeta and Nemertini. Besides the index $\bar{A} P^{1 / 2}$ the following values are given: mean and maximum abundance $\left(\bar{A}, A_{\max }\right)$, mean abundance in the heavily polluted zone $\left(\overline{\mathrm{A}}_{50-300 \mathrm{~m}}\right)$, mean and maximum biomass $\left(\overline{\mathrm{B}}, \mathrm{B}_{\mathrm{max}}\right)$, mean and maximum dominance $(\overline{\mathrm{D}}$, $D_{\max }$ ), and frequency $(P)$. All values except $\bar{A}_{50-300 \mathrm{~m}}$ refer to the slightly affected and unpolluted zones only.

Table 4 indicates that euryoeceous species (cf. Figs 4-7) dominate the sand community, while characteristic animals have a medium or lower place in the rank.

\section{Life forms}

Sand gives the best possibilities for expansion for deposit feeders. They form the dominating group with $58 \%$ of the species and $90 \%$ of the individuals. Predators, with $26 \%$ of the species and just $1 \%$ of the individuals and suspension feeders with $16 \%$ of the species and $9 \%$ of the individuals are less important. The commonest (euryoeceous) selective deposit feeders (Capitella capitata, Pygospio elegans), together with those suspension feeders capable of ingesting coarser particles (Mya arenaria, Mytilus edulis) and very unspecialized predators (Nereis diversicolor), are favoured by sedimenting organic substances. Thus it can be stated that the sandy bottom macrofauna is preadapted to transform a high amount of sewage particles to valuable biomass for the food web (cf. Fig. 9). It must be assumed that it carries out a large portion of the self purification of the whole ecosystem of Kiel Bay. 
Influence of sewage pollution on benthic communities

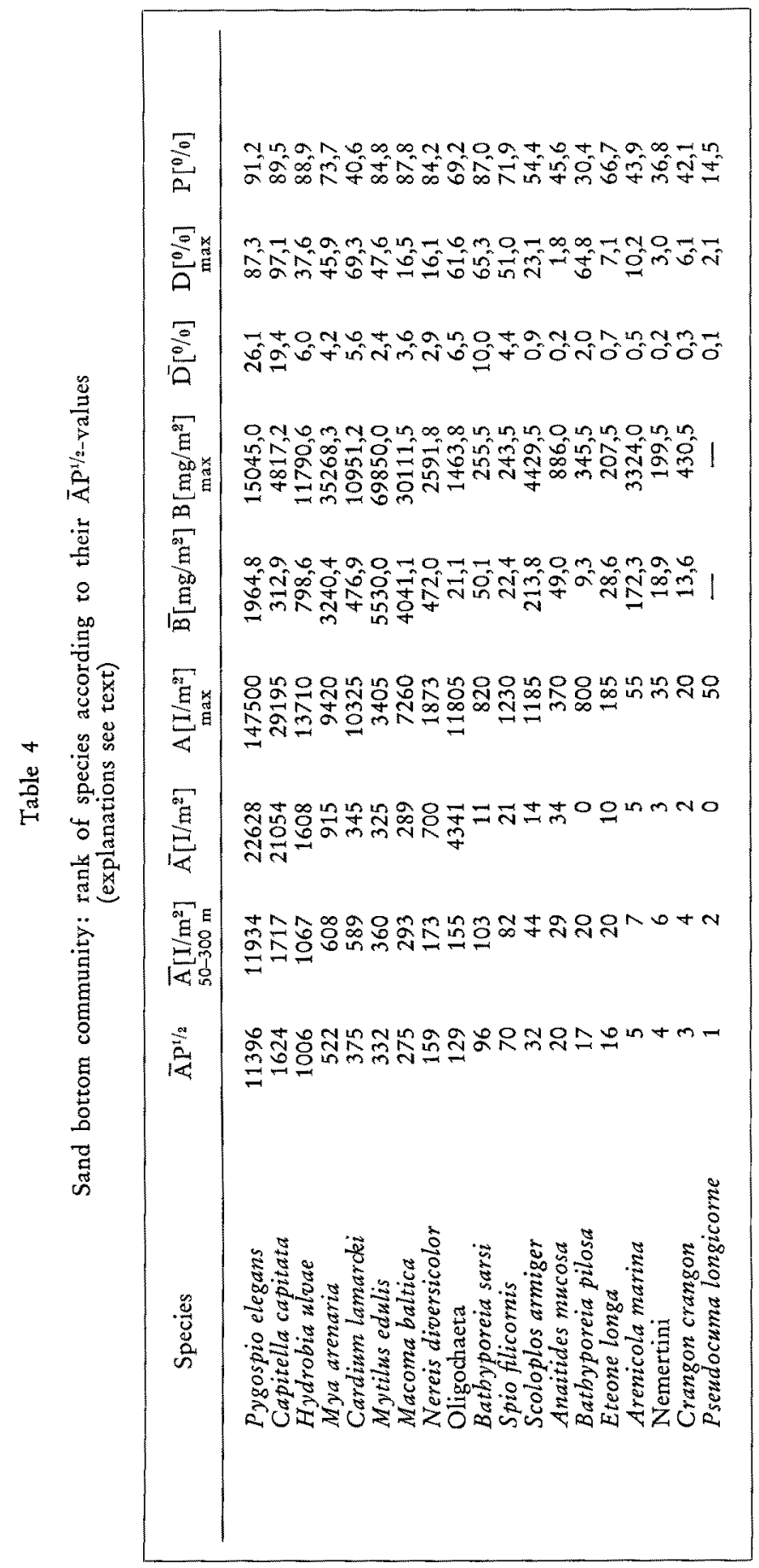


Most of the sand bottom species $(53 \%)$ and $80 \%$ of the individuals belong to the hemisessile infauna. Motile animals, mostly predators, are much less numerous, but provide relatively many species.

\section{Faunal composition in the pollution gradient}

Figure 8 shows the strong influence of sewage pollution on the composition of the macrobenthic fauna (annual mean). Within a radius of about $100 \mathrm{~m}$ Capitella capitata is clearly dominant. From 200 to $700 \mathrm{~m}$ it becomes less important compared with Pygospio elegans. Beyond this zone the diversity becomes greater, miscellaneous species become more prominent in the community; Batbyporeia sarsi becomes more frequent and numerous, indicating a rather clean sand.

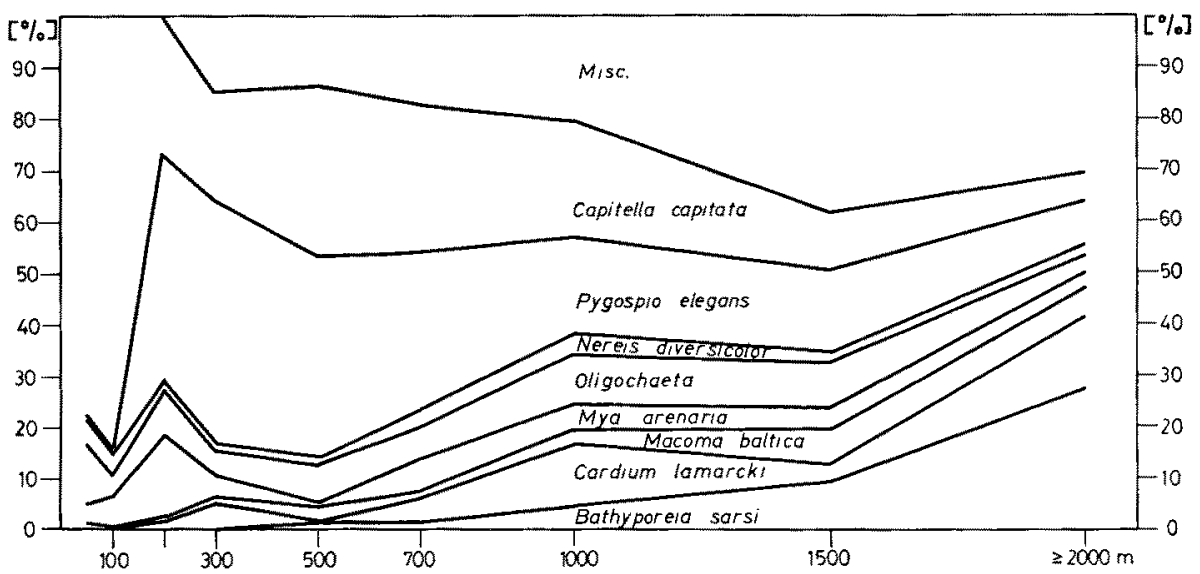

Fig. 8: Macrofauna composition in the pollution gradient (sand bottom)

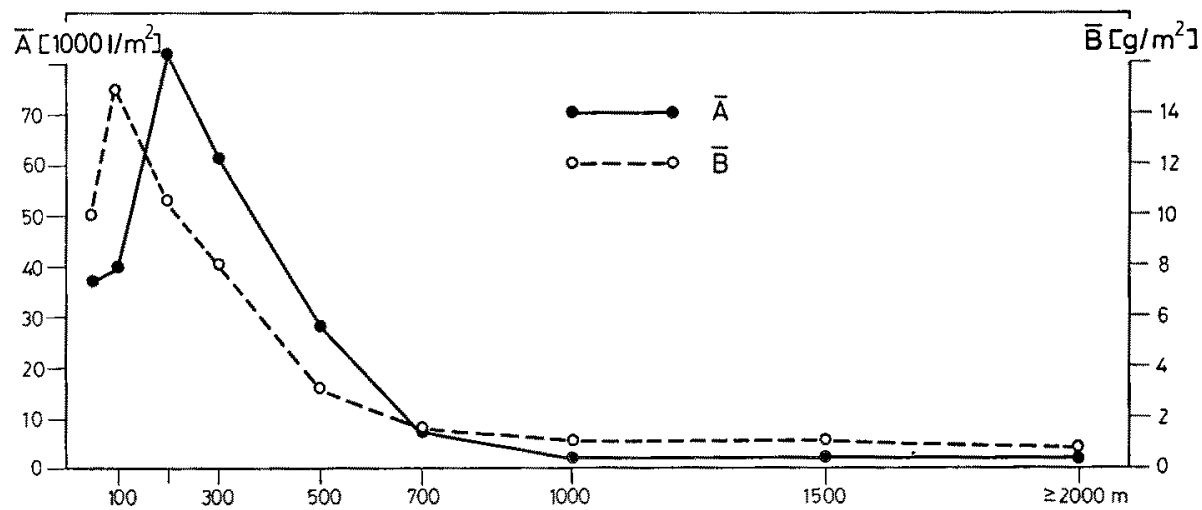

Fig. 9: Sand bottom macrofauna: mean abundance $(\bar{A})$ and biomass $(\bar{B})$ in the pollution gradient 
As stated above, correlated with feeding types, a remarkably great rise of production occurs in the polluted zone of the sand flats. It appears as a multiplication of mean biomass by a factor of 15 and of mean abundance by a factor of 50 (Fig. 9). Thus it exceeds the average considerably (cf. Fig. 1). This fact underlines again the eminent importance of the sand dwelling inshore macrofauna for the self-purification of the whole ecosystem.

Nevertheless one must take into consideration the fact that a high transformation of sewage to biomass is not positive per se, since it is linked with an equally high accumulation of toxic substances which also occur in sewage from municipalities. The second danger to be borne in mind is still largely unknown in its consequences for the ecosystem: the decline of species diversity.

There are at least two reasons for this pauperization. The primary one is a direct stress situation caused by sedimenting particles and cellulose fibres contaminating and clogging the habitat niches, and filter and gill apparatus. This must account for the fact that Capitella capitata and all other species non-selective for habitat and food show a conspicuous decrease of population densities in the severely polluted zone $(50-100 \mathrm{~m}$ radius; see Figs. 1 and 9). Mainly in the semipolluted zone a second effect is important: With the increase in food supply by sewage particles, euryoeceous, preadapted populations compete more successfully for space in the biotope. More sensitive and specialized species are repressed in two ways under those conditions.

Figure 10 shows the behaviour of diversity and species number in the pollution gradient. In order to compare some current diversity indices and to ascertain the trend disussed above the following measures were used:

$$
\begin{aligned}
& \text { (1) } \mathrm{H}^{\prime}=-\sum_{\mathrm{i}=1}^{\mathrm{S}} \frac{\mathrm{N}_{\mathrm{i}}}{\mathrm{N}} \mathrm{ld}\left(\frac{\mathrm{N}_{\mathrm{i}}}{\mathrm{N}}\right) \begin{array}{l}
\text { (Shannon \& Weaver, 1949; } \\
\text { cf. also Pielou, 1966a, b, 1969) }
\end{array} \\
& \text { (2) } \mathrm{F}=1-\sum_{\mathrm{i}=1}^{\mathrm{S}} \frac{\mathrm{N}_{\mathrm{i}}\left(\mathrm{N}_{\mathrm{i}}-1\right)}{\mathrm{N}(\mathrm{N}-1)} \quad \text { (Simpson, 1949; Pielou, 1969) } \\
& \text { (3) } D_{\mathrm{s}}=1 / \sum_{\mathrm{i}=1}^{\mathrm{S}} \frac{\mathrm{N}_{\mathrm{i}}\left(\mathrm{N}_{\mathrm{i}}-1\right)}{\mathrm{N}(\mathrm{N}-1)} \quad \begin{array}{l}
\text { (SMMPSON, 1949; MCARTHUR \& Wilson, } \\
\text { 1967; MCARTHur, 1972). }
\end{array}
\end{aligned}
$$

The evenness component of species diversity was calculated as

$$
J^{\prime}=\frac{\mathrm{H}^{\prime}}{\mathrm{ld} \mathrm{S}} \quad \text { (Pielou, 1966a, b, 1969) }
$$

The observations on the faunal compositions indicate a disturbance of the subsystem as a consequence of pollution stress. This is confirmed by all measures of diversity and evenness (Fig. 10). The curves are inversely correlated with the mean abundance and biomass (Fig. 9), and also with the dilution and ignition loss values. The mean number of macrobenthic species $(\bar{S})$ shows a diverging trend: There is a slight maximum in the semipolluted zone around $300 \mathrm{~m}$ distance from the outlet. This apparant anomaly can be explained by a sort of "edge effect". Several euryoeceous aufwuchs dwellers, which normally do not occur in pure sand, live frequently in organically enriched sediment (e. g. Corophium insidiosum, Microdeutopus gryllotalpa, Ido- 


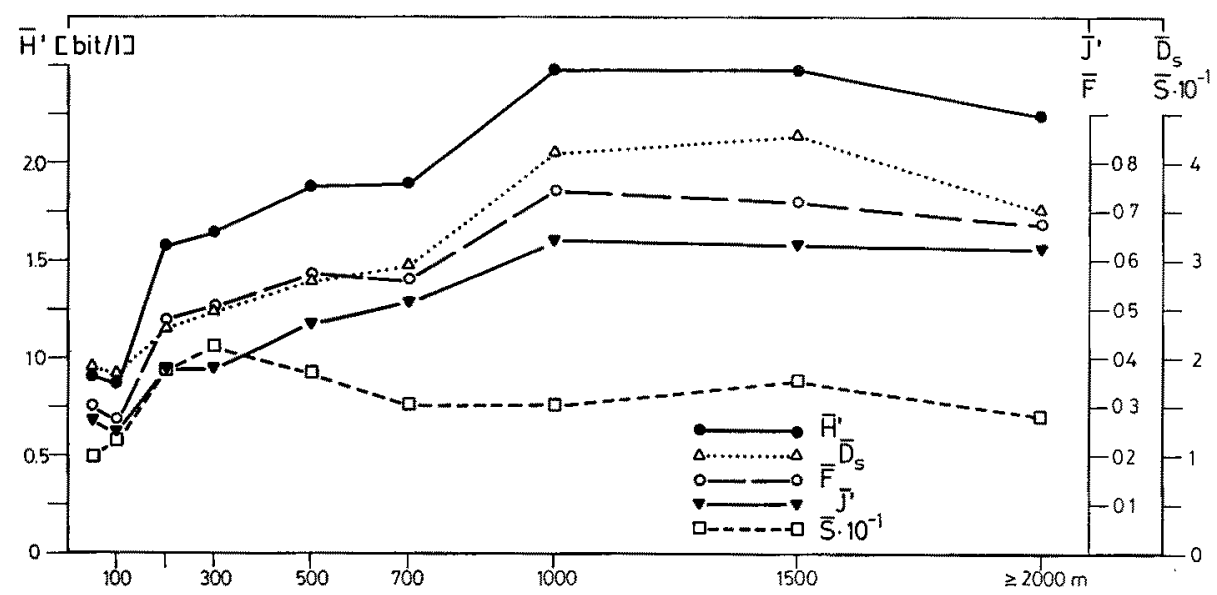

Fig. 10: Sand bottom macrofauna: mean number of species $(\bar{S})$ and diversity in the pollution gradient

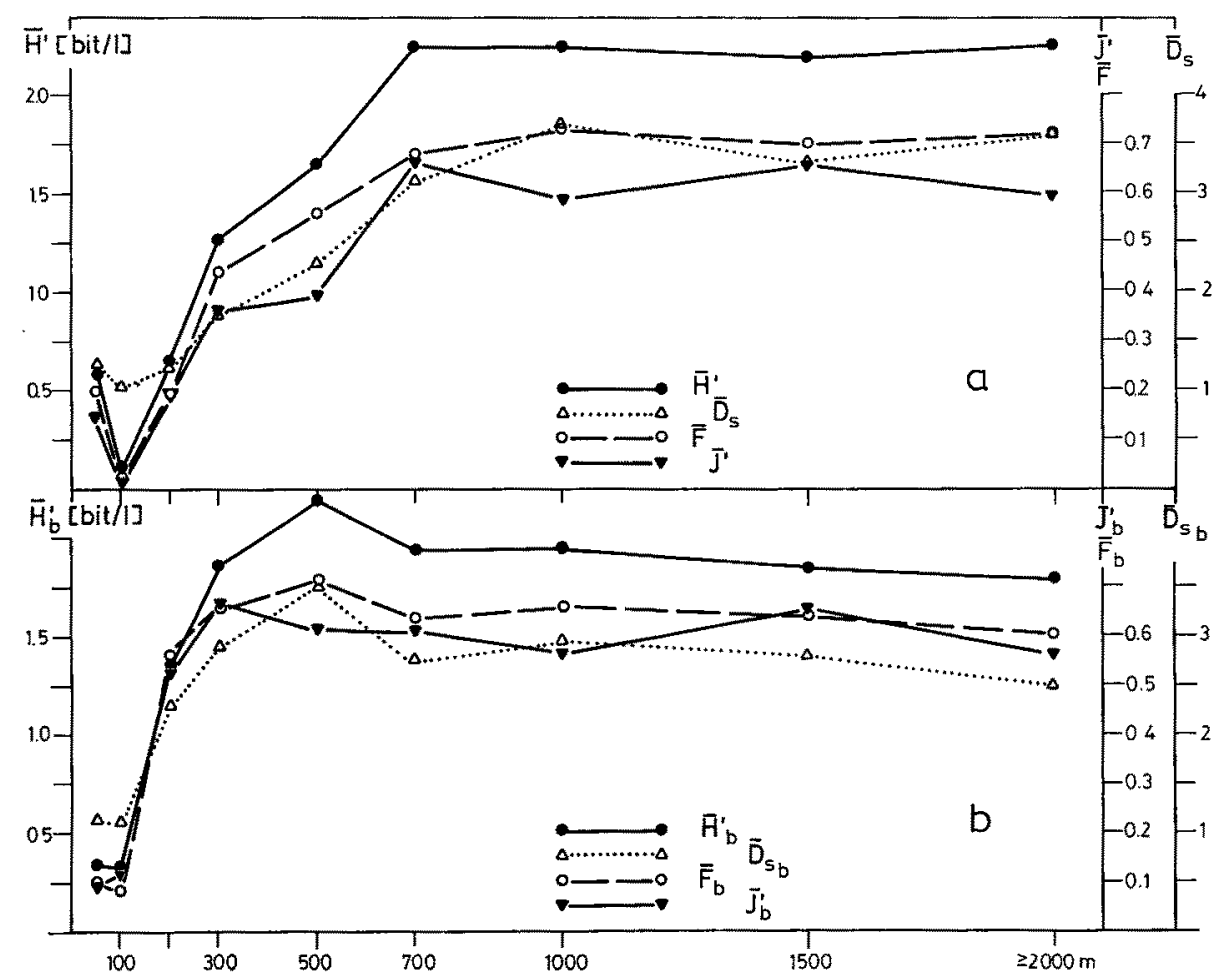

Fig. 11. Sand bottom macrofauna: comparison between numerical (a) and biomass (b) diversity in the pollution gradient 
tea baltica, Gammarus salinus, Gammarus oceanicus). Here the sand is pure enough to allow the survival of sensitive species and sufficiently enriched to harbour animals of the Capitella-type (Capitella capitata, Naididae, Tubificidae).

Thus is can be formulated that in a sand bottom subsystem, environmental stress mainly affects the evenness component. This agrees well with the hypothesis of TrAmER (1969) that under unpredictable, in some respect extreme, conditions diversity is regulated by the evenness, while a predictable (stable) system is regulated by the species richness.

The diversity values are negatively correlated with the amounts of biomass (e. g. $\mathrm{H}^{\prime} / \overline{\mathrm{B}}: \mathrm{r}=-0,42, \alpha<0,1 \%$ ). This observation corresponds to the results of GHILARov \& TrMonIn (1972) and the widespread postulate that a system low in diversity needs a higher production rate for its maintainance because of a lower energy utilization (lack of specialists!).

One single sample series (15, 6. 1972, all sand) was used as an example for the comparison between numerical and biomass diversity (Fig. 11). Both indices show the same trend, but it is obvious that biomass diversity $\left(\overline{\mathrm{H}}^{\prime} \mathrm{b}\right.$ etc.) reaches its constant value much nearer to the outlet due to a high evenness $\left(\bar{J}^{\prime}\right)$. This early stabilization of the curve is caused by mass populations of very small animals (Pygospio elegans, Capitella capitata). They neutralize the influence of rarer but heavier species on the evenness component of diversity. Except for MCARTHUR's index there is a close relation $(\alpha<5$ or $1 \%$ ) between numerically and biomass based diversity values. Biomass diversity seems to be a worse measure for pollution gradients but surely it is a better expression for metabolic processes in the benthic subsystem.

\section{The eel grass community}

The eel grass subsystem can only be understood if considered together with the surrounding and adjoining sand bottom. This is altered by the plants in a characteristic way: (1) Roots and a water movement decreased by leaves and blades of Zostera marina reduce overturn and transport and firm the bottom. (2) Dead plant parts enrich the sediment with organic substances. (3) The plant itself enables sessile organisms and species preferring phytal and hard bottom to settle on it.

At the same time the typical sand dwelling animals are still present. Eel grass therefore attracts many species from other communities, but contains hardly any specific forms (Table 5). As in the sand bottom community, euryoeceous species dominate the more specific inhabitants (Table 6).

The composition of the feeding types is changed compared with the pure sand community. Most of the species $(41 \%)$, but in accordance with ExtoN's pyramid only a minority of the mean total individual number $(3 \%)$, live as predators. Deposit feeders are still in the forefront (31\% of the species, $67 \%$ of all individuals), but now suspension feeders also play a considerable role (species: $28 \%$; individuals: $30 \%$ ). The rise of predators corresponds to a rise of motile species $(63 \%$ of the species number, $20 \%$ of all individuals). Since a Zostera subsystem is somewhat stabilized (see above) and contains more (and rarer) species, pollution effects must be assumed to concern not 
Table 5

Eelgrass community: Species grouped according to their substrate specifity (explanations see Table 3)

\begin{tabular}{|llll|}
\hline $\mathrm{a}$ & $\mathrm{b}$ & $\mathrm{c}$ & $\mathrm{d}$ \\
\hline Lacuna & Fabricia sabella & Cardium lamarcki & Arenicola marina \\
divaricatat & Crangon crangon & Anaitides mucosa & Mytilus edulis \\
& Calliopius & Corophium & Capitella capitata \\
& laeviusculus & insidiosum & Nereis diversicolor \\
& Rissoa inconspicua & Asterids rubens & \\
& Scoloplos armiger & Gammarus oceanicus \\
& Mya arenaria & Idotea baltica & \\
& & Polydora ciliata & \\
& Microdentopus & \\
& gryllotalpa & \\
& & Polydora ligni & \\
& & Littorina littorea & \\
& & Gammarus salinus & \\
& & Mydrobia ulvae & \\
& & Macoma baltica & \\
& & Pygospio elegans \\
& &
\end{tabular}

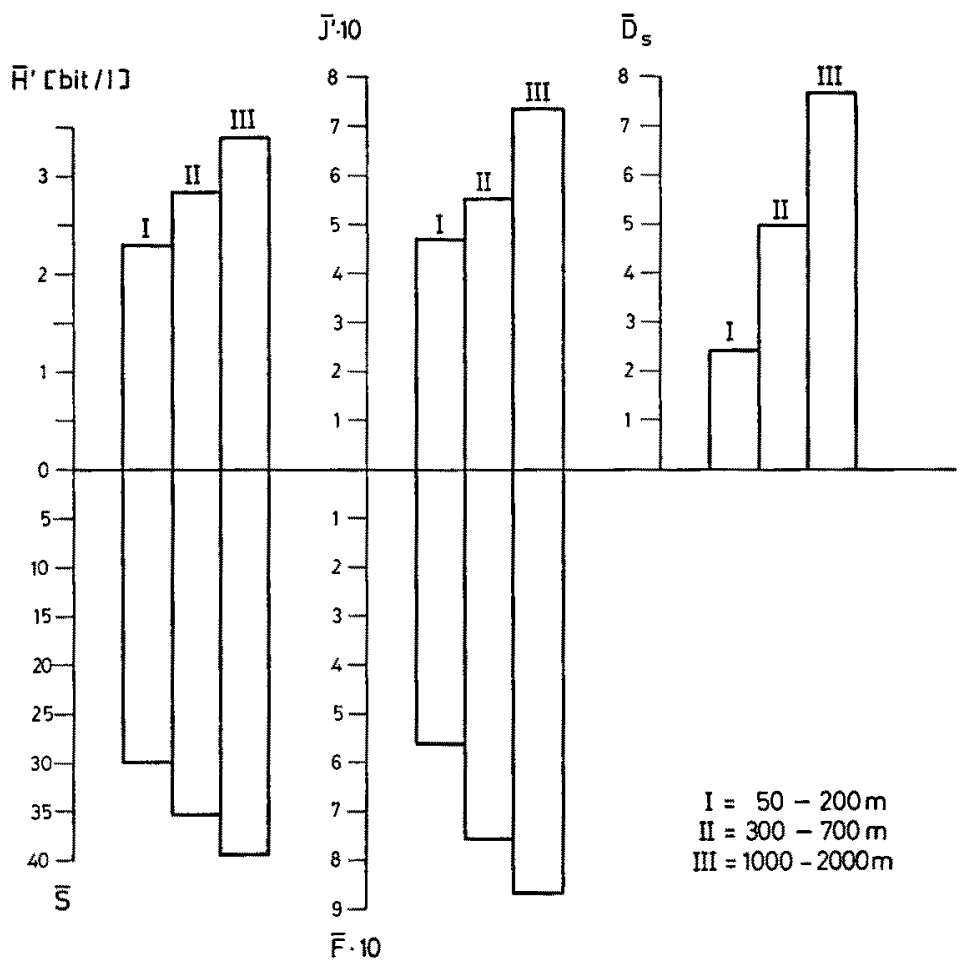

Fig. 12: Eel grass macrofauna: mean number of species $\overline{(S)}$ and diversity in the pollution gradient 


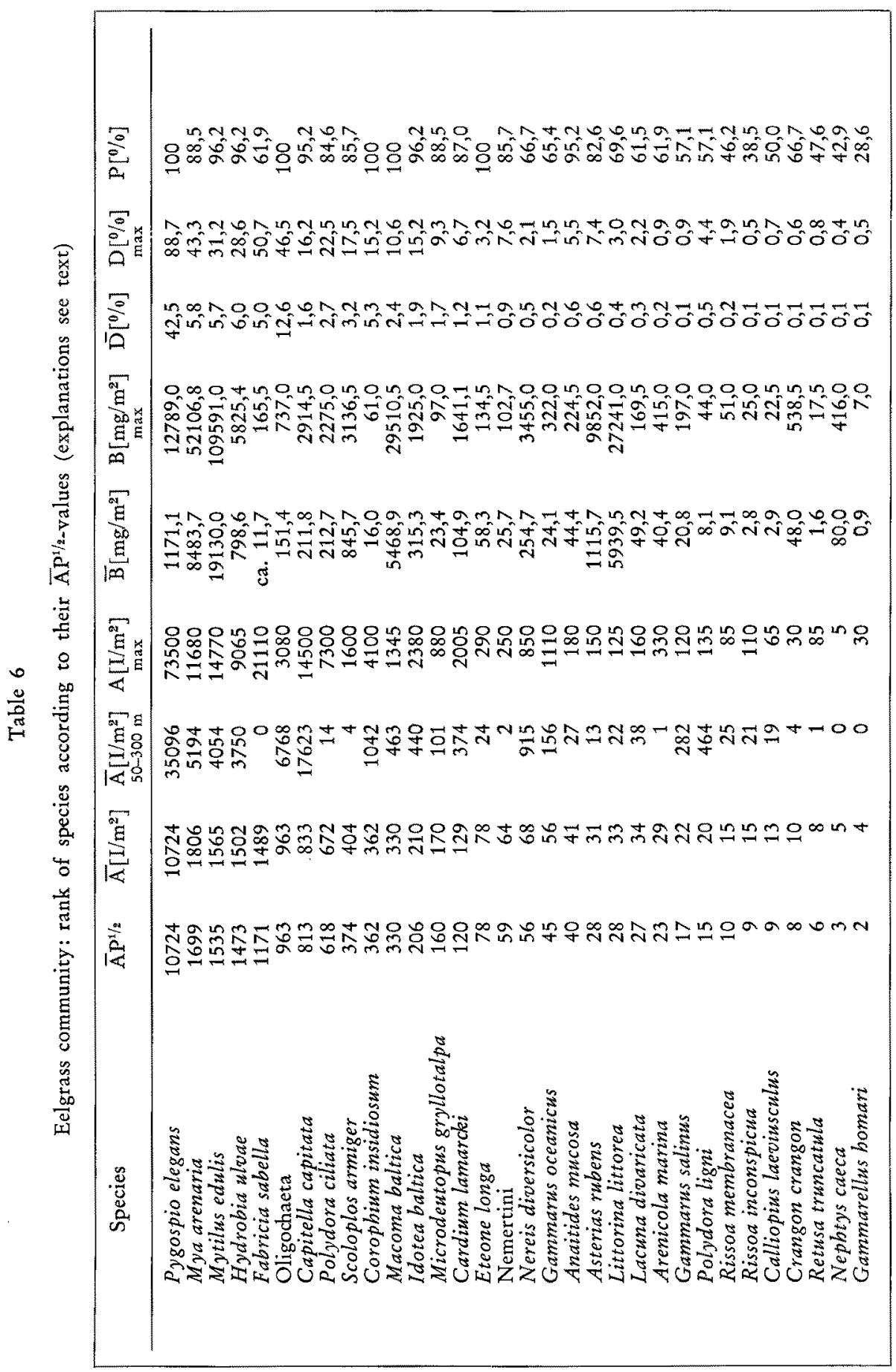


only the evenness, but also the species richness component. This supposition is confinmed by the measurement of diversity (Fig. 12). The evennes is lowest in the semipolluted zone (II) because of mass populations of Pygospio elegans occurring here. The mean number of species is more than twice as high as in sand communities. The increase of biomass production by organic enrichment is also notable (Fig. 13).

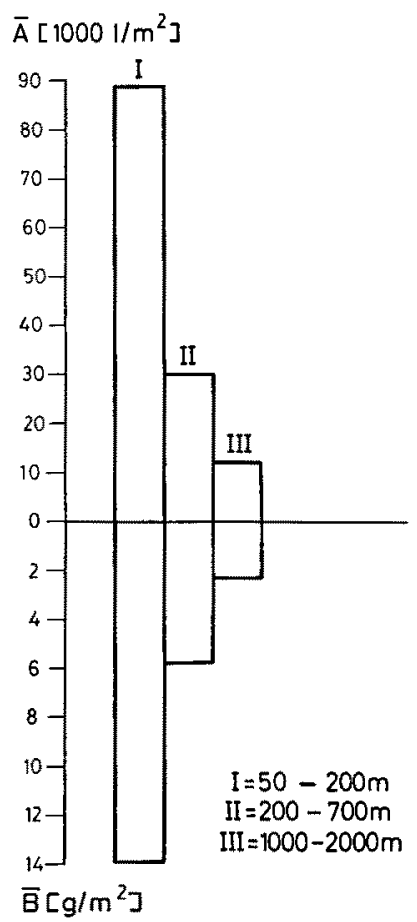

Fig. 13: Eel grass macrofauna: mean abundance $(\bar{A})$ and biomass $(\bar{B})$ in the pollution gradient

Table 6 shows that this can be attributed to the same species as on the sand bottom. The importance for the transformation of organic pollutants and thus for the self purification of the system is of the same order of magnitude.

\section{The mussel bed community}

Even more than Zostera plants, accumulations of mussels change the sandy biotope: (1) The stabilization of the bottom is highest under a nearly closed cover of shells. (2) Organic substances are enriched in the spaces between the shells. (3) The shells as hard bottom fragments make the formation of phytal possible.

The mussel bed subsystem thus has some peculiarities which allow it to be better described by means of characteristic species. As can be seen in Figures 6 and 7, its macrofauna is much more similar to that of the Zostera than that of the sand com- 
munity. The main properties of the subsystem are biologically controlled. Table 7 indicates a high amount of characteristic species. Group " $a$ " can also include some rarer species, which also clearly prefer mussel beds as habitat: Nereis pelagica, Nereimyra punctata, Harmotboe imbricata, Halacarus basteri, Caprella linearis, Brachystomia rissoides.

\section{Table 7}

Mussel bed community: Species grouped according to their substrate specifity (explanations see Table 3 )

\begin{tabular}{|c|c|c|c|}
\hline$a$ & b & c & $\mathrm{d}$ \\
\hline $\begin{array}{l}\text { Balanus crenatus } \\
\text { Harmotboe impar } \\
\text { Nereis succinea } \\
\text { Jaera albifrons } \\
\text { Pboloe minuta } \\
\text { Carcinus maenas }\end{array}$ & $\begin{array}{l}\text { Polydora ligni } \\
\text { Microdeutopus } \\
\quad \text { gryllotalpa } \\
\text { Gammarus salinus } \\
\text { Coropbium } \\
\text { insidiosum } \\
\text { Asterias rubens } \\
\text { Polydora ciliata } \\
\text { Littorina littorea } \\
\text { Gammarus oceanicus } \\
\text { Idoted baltica } \\
\text { Mytilus edulis } \\
\text { Arenicola marina }\end{array}$ & $\begin{array}{l}\text { Rissoa inconspicua } \\
\text { Fabricia sabella } \\
\text { Calliopius } \\
\text { laeviusculus } \\
\text { Anatides mucosa } \\
\text { Cardium lamarcki" } \\
\text { Capitella capitata }\end{array}$ & $\begin{array}{l}\text { Mya arenaria* } \\
\text { Nereis diversicolor } \\
\text { Macoma baltica* } \\
\text { Pygospio elegans } \\
\text { Hydrobia wlvae } \\
\text { Scoloplos armiger }\end{array}$ \\
\hline
\end{tabular}

It can be noted that Mytilus edulis is the most important but not the most characteristic species (Tables 7,8 ). Opportunists also dominate the $\bar{A} \mathrm{P}^{1 / 2}$ rank in mussel beds (Table 8 ).

The number of feeding types is increased by the parasitic snail Brachystomia rissoides, which is, however, rather unimportant. As in the Zostera community, predators take the first rank among the species $(45 \%)$, but provide only $6 \%$ of the individuals. Deposit feeders (species: $23 \%$, individuals: $45 \%$ ) are displaced from their prominent rank by suspension feeders (species: $29 \%$, individuals: $54 \%$ ). The community structure resembles hard bottom biocoenoses, where the importance of the pelagic system and an unusual richness of species and life forms are also typical.

Sessile filter feeding epifauna (Mytilus edulis, Balanus crenatus) is of great importance compared with sediment dominated systems. Motile animals (mostly predators) provide $58 \%$ of all species and $19 \%$ of all individuals.

The percentage of hemisessile infauna in the individuals is decreased from $80 \%$ in pure sand and $73 \%$ in eel grass to only $51 \%$ in mussel beds.

In the pollution gradient an interesting phenomenon becomes obvious: The rise of mean biomass and abundance is much more weakly pronounced here than on the other substrate types (Fig. 14). From Table 8 it can be concluded that the euryoeceous species are not able to increase their population densities to the same extend they do in sandy biotopes. This holds true even for species which prefer mussel beds as habitat (e. g. Capitella capitata). The causes and significance of this will be discussed below. 


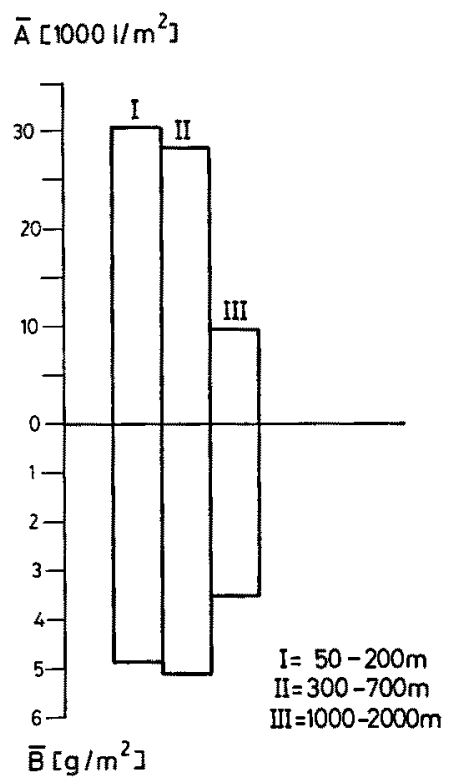
Fig. 14: Mussel bed macrofauna: mean abundance $(\bar{A})$ and biomass $(\bar{B})$ in the pollution

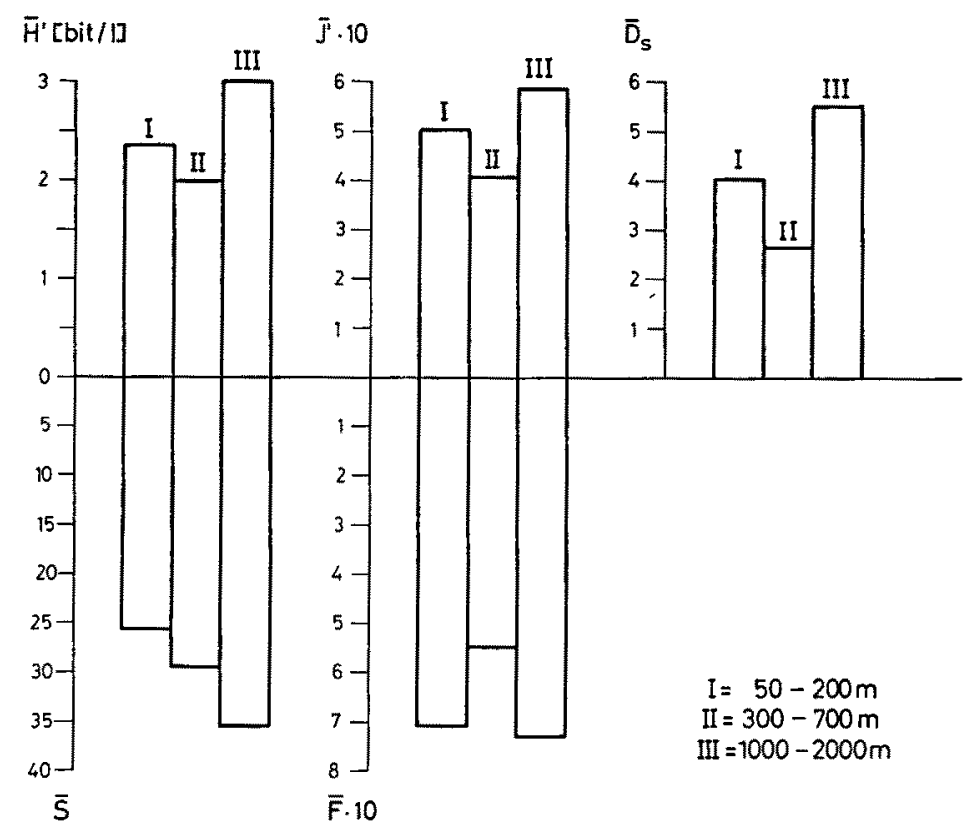

Fig. 15: Mussel bed macrofauna: mean number of species $(\overline{\mathrm{S}})$ and diversity in the pollution gradient 


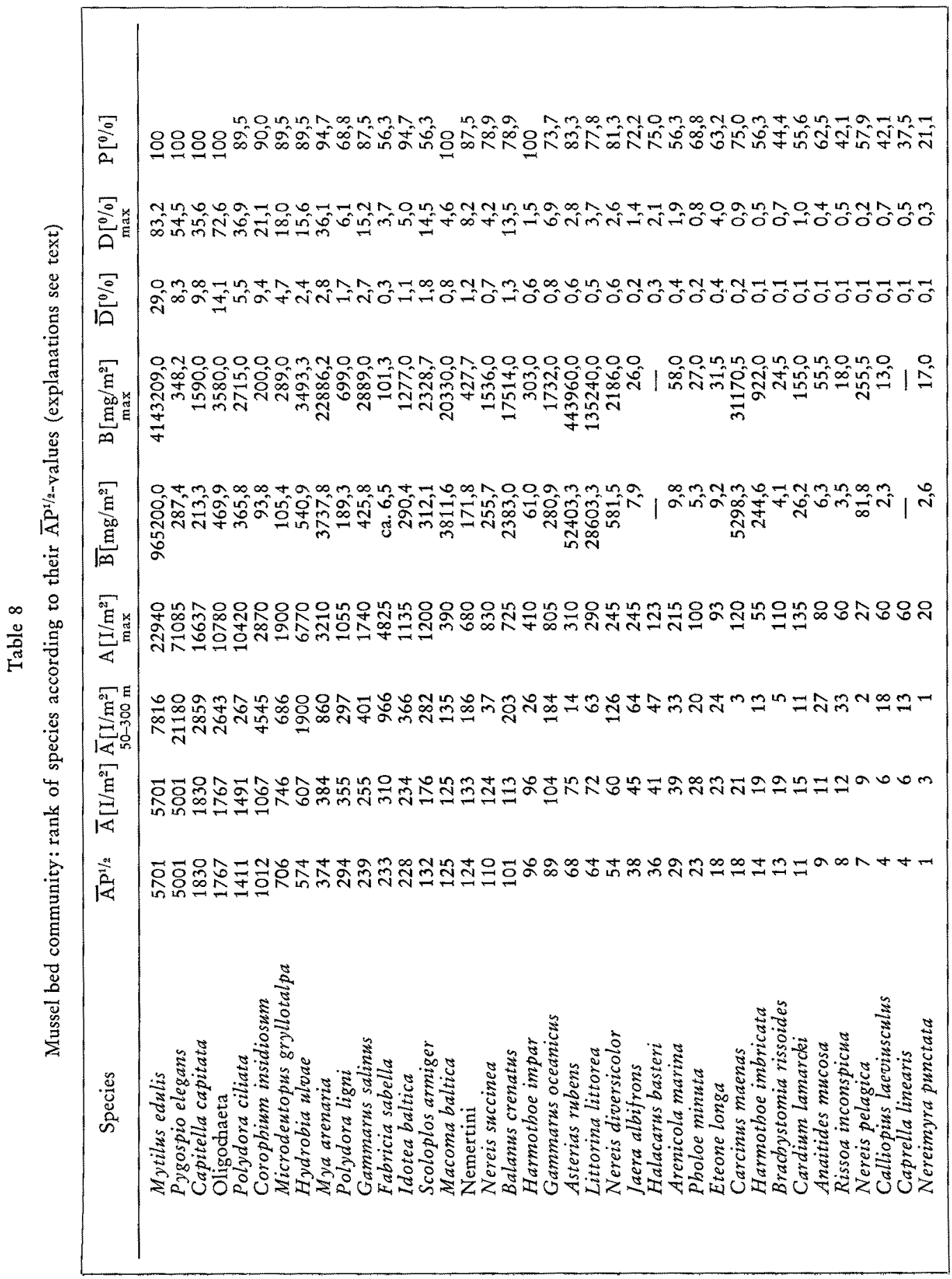


Diversity and mean number of species are highest in mussel beds (Fig. 15). The negative effect of pollution on both species richness and evenness is evident.

\section{COMPARISON OF THE COMMUNITIES AND DISCUSSION}

The investigated area belongs to the "shallow inshore benthos" subsystem within Kiel Bay. It contains continua and well defined communities. The pollution gradient creates a continuum, which is partly superimposed on the second type of subordinate subsystems characterized by the substrate properties. Thus the communities of the different substrate types are more similar to each other under the influence of sedimenting sewage particles. In the strongly affected (physically controlled) zone a group of euryoeceous species is predominant, nearly independently of the biotope structure. At greater distances from the sewage outfall the communities are rather more biologically controlled. Mussel beds and eel grass promote similar dhanges in the sand bottom, which include stabilization and partial covering of the sediment, enrichment of organic material, provision of hard bottom fragments, etc. The consequence is a much greater similarity between the Zostera and Mytilus communities than occurs between pure sand and any other substrate. The sand and eel grass communities are of course closer related than sand and mussel beds, since the sediment factor is important to a different degree. In Figure 16 these relationships are quantified as reciprocal JACCARD-indices of faunal similarity. The greater the similarity of community composition the nearer two subsystems appear in the triangle.

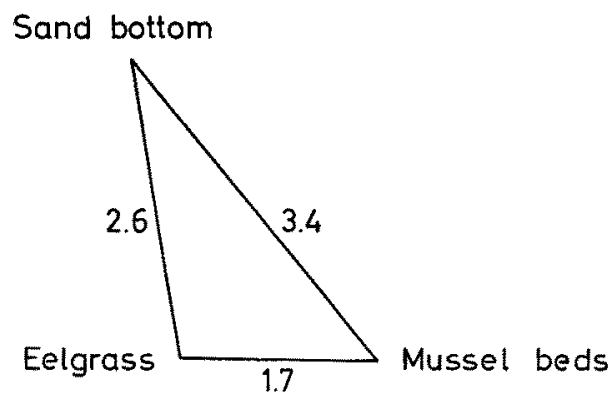

Fig. 16: Faunal similarity of the three main substrate types, expressed as reciprocal Jaccard-
index

Comparing the communities as regards life forms in the sequence sand - eel grass - mussel beds the following trends can be observed (Fig. 17, 18): (1) rise of predators, (2) strong decrease of deposit feeders, (3) strong rise of suspension feeders, (4) rise of sessile epifauna, (5) decrease of hemisessile infauna, and (6) rise of motile species (mainly epifauna).

These trends are caused by spatial structure and linked factors. The vertical expansion of the biotope linked to the covering of the sediment increases the importance 
of the near bottom water for the benthic fauna. Some typical species are good swimmers (amphipods, isopods, some polychaetes).

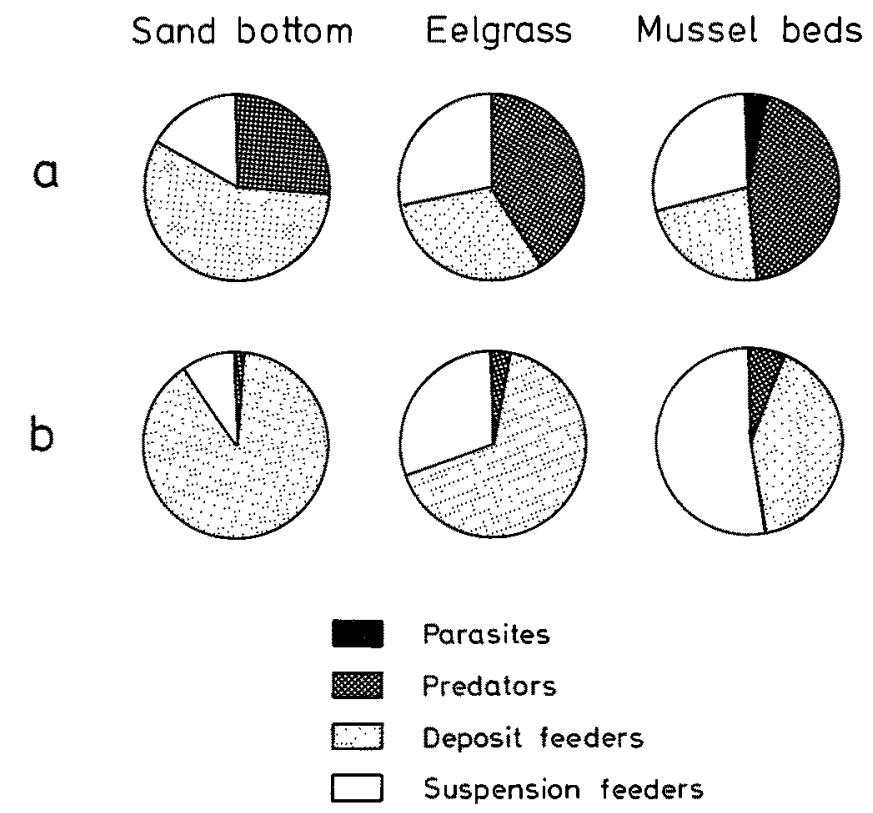

Fig. 17: Substrate types: mean percentage of the main feeding types $(a=$ species, $b=$ individuals)

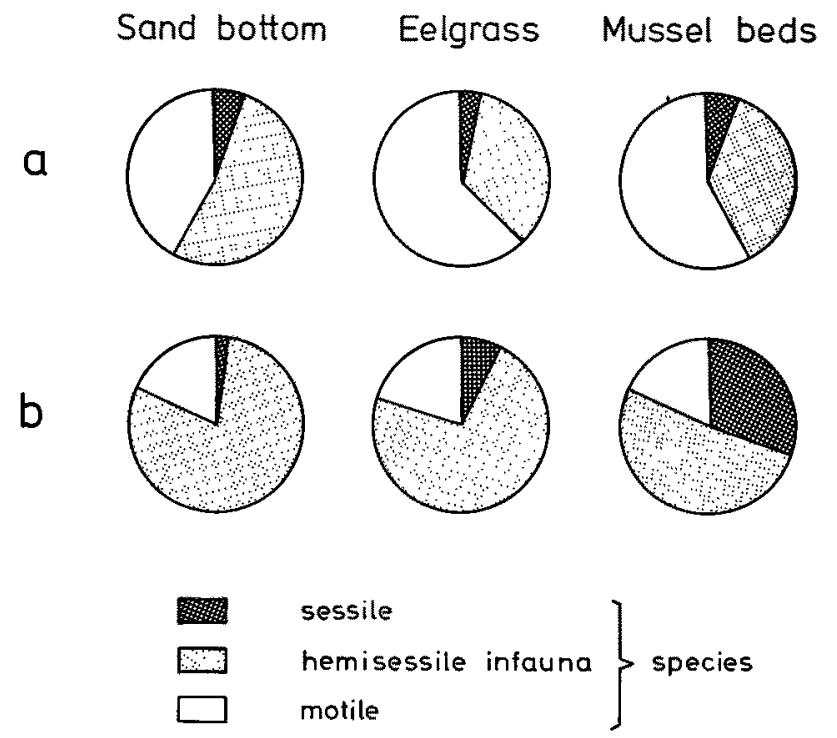

Fig. 18: Substrate types: mean percentage of the settling types $(a=$ species, $b=$ individuals $)$ 
The complication and stabilization of the abiotic environment provides a greater capability of accommodating more specialized species in more ecological niches (Fig. 19). The consequence is an increased diversity (Fig. 20).

\section{Sand bottom Eelgrass Mussel beds}

a
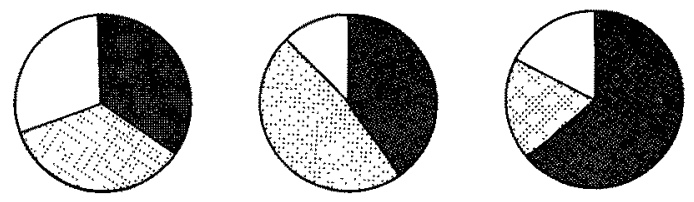

b
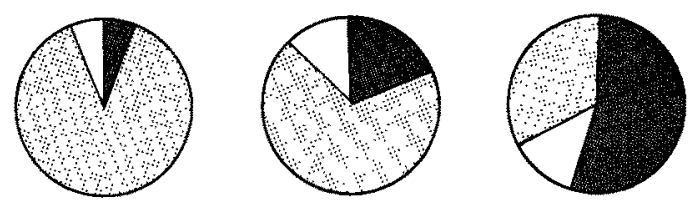

Species specific as regards relative frequency and/or abundance

3 "more frequent and/or abundant on two substrates

$\square$ Indifferent species as regards relative frequency and/or abundance

Fig. 19: Substrate types: Specifity of the fauna $(a=$ species, $b=$ individuals)

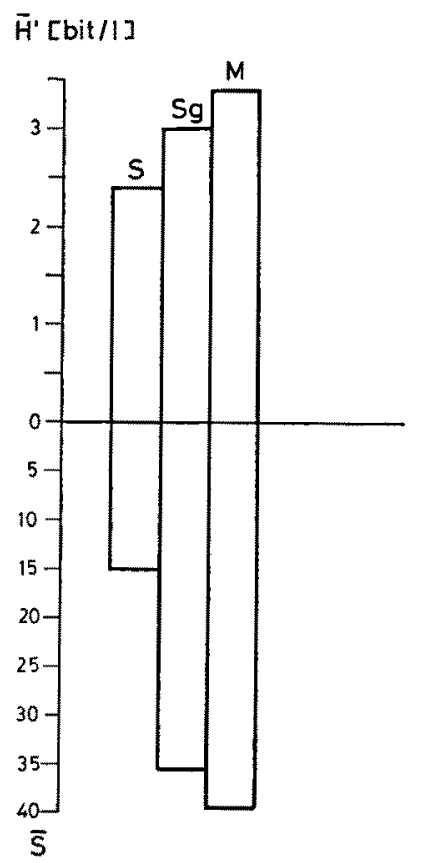

Fig. 20: Substrate types: mean number of species ( $\bar{S})$ and diversity 
As shown above, sediment communities rather low in diversity react to sedimentation of organic material by producing mass populations of a few generalists. In more highly diverse systems population increases are far weaker. Here strong competition and predation by many specialized species takes place and hinders the development of mass populations. This biological control can be regarded as an ecological buffer of the system against one type of environmental fluctuation: the regulation sets in if those stress factors which selectively favour a few preadapted generalists are rising. Sedimentation of organic debris, for example, favours euryoeceous deposit feeders in particular. Simply organized systems (e. g. sand) are not buffered to this extent. Since they contain mainly generalists, the reactions of the community appear as extreme oscillations of evenness and production.

The trend shown by this comparison confirms partly the diversity - stability hypothesis (MCARTHur, 1955). Nevertheless it cannot be generalized that higher diversity is basically identical with better self regulation or stronger resistence. Rather the character of the disturbance is decisive: some evidence is given that the relationship stated above is valid only for factors influencing the evenness component of diversity directly (see above), but not for those primarily affecting the species richness component (e.g. poisonous substances). The last mentioned factor type probably has much more catastrophic effects in complex systems containing more specialized and sensitive species than in simpler ones with their mainly euryoeceous species.

These statements upon the relationships among biotope and community structure, environmental stability, diversity and resistance against external disturbances are to be regarded as widely hypothetical rules. They must be scrutinized again in practice to become important for predictions on the behaviour of ecological systems under known conditions.

Bacteria and microfauna, but to a certain extent also, the inshore benthic communities, play an important role for the transformation of particulate organic matter to utilizable biomass (mainly food for flatfishes). Subsystems naturally low in diversity have a far greater capacity than highly diverse ones. The attainable maximum limited by competition for space was observed in sand bottoms as a mean rise of population density by a factor of 50 and of biomass by a factor of 15 . A heavier sedimentation of sewage particles decreases the capability of the benthic community to assimilate them (cf. Figs. 1 and 9). The transformation of organic pollutants to available food prevents a suffocation of the marine ecosystem and raises its productivity, but at the same time it creates the danger of accumulation of heavy metals, pesticides and other poisonous substances by the same factor. A second danger, especially for the Baltic Sea, is eutrophication by dissolved nutrients and as a consequence the contamination of the deeper areas by the release of hydrogen sulphide.

From the greater fluctuations of evenness and production caused by disturbances in subsystems of rather simple structure (e. g. sand), it can be deduced that these communities are good indicators for stress factors which affect evenness. Communities of highly complex systems (e. g. mussel beds) are probably better indicators for factors which decrease species richness.

The practical value of this knowledge is that it points out a possible ecological method of measuring environmental stress. It complements physical and chemical 
Table 9

Survey of significant species of macrofauna in the study area

\author{
Mol1usca \\ Lacuna divaricata FABRICIUS \\ Littorina littorea $\mathrm{L}$. \\ Hydrobia ulvae PenNant \\ Rissoa membranacea ADAMs \\ $R$. inconspicua ALDER \\ Bracbystomia rissoides HANLEY \\ Retusa truncatula BRUGIERE \\ Mytilus edulis L. \\ Cardium lamarcki REEVE \\ Macoma baltica L. \\ Mya arenaria L. \\ Annelida \\ Harmothoe imbricata L. \\ H. impar JoHNSTON \\ Pholoe minuta FABRICIUS \\ Eteone longa FABRICIUS \\ Anaitides mucosa OERSTED \\ Nereimyra punctata O. F. MüLleR \\ Nereis pelagica L. \\ N. diversicolor O. F. MÜLLER \\ N. succinea LEUCKART \\ Nephtys caeca Fabricius \\ Scoloplos armiger O. F. MÜLLER \\ Spio filicornis O. F. MÜLLER \\ Polydora ligni WeBSTER
}

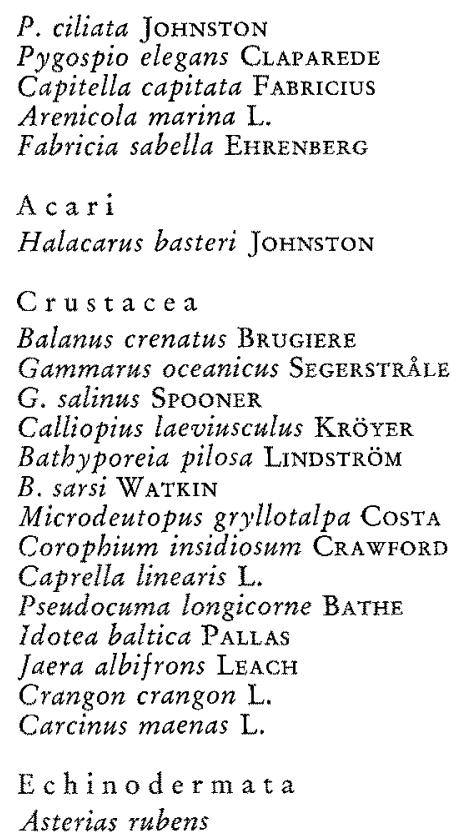

evaluations, since the community structure reflects the long term situation of its biotope by effectively carrying out the integration of all factors which otherwise must be continuously measured over a long period and fed into a computer. The precondition for using benthic communities as indicators of environmental quality is the further study of all basic structural and functional relationships. The last step will be the building of a comprehensive model for the description, understanding and simulation of the endangered ecosystem.

\section{SUMMARY}

1. The influence of organic sewage pollution on the macrobenthic community structure of a shallow inshore region was studied in the South of Kiel Bay (Baltic Sea).

2. The sandy bottom bears three associations within the pollution gradient. They can be characterized by: (a) Capitella capitata and Oligochaeta $(50-100 \mathrm{~m}$ distance from the sewage outlet), (b) Pygospio elegans (200-ca. $700 \mathrm{~m}$ ) and (c) Batbyporeia sarsi $(>700 \mathrm{~m})$. They have no distinct borders but resemble rather a continuum.

3. In the less affected reaches the influence of biological substrate structure becomes more evident. Distinct associations can be distinguished. 
4. The combination of life forms, number of species, diversity and other community features depend on the degree of the substrate's spatial heterogenity in a characteristic way. They are also strongly influenced by the extent of pollution.

5. The inshore benthic macrofauna provides an important contribution to the self purification of the whole ecosystem by transforming particulate organic matter to available fish food. Abundance and biomass are multiplied due to sewage sedimentation. This process creates the danger of accumulation of poisonous substances in addition to the eutrophication problem.

6. More highly diverse systems (e. g. mussel beds) resist better those factors which directly influence the evenness of the community. The ecological buffer consists of many specialized competitors and predators. Systems low in diversity (e. g. sand) react much more strongly to disturbances of this type.

7. Faunal composition, evenness, species richness, population density and biomass of the communities are suitable parameters of an ecological method for the early recognition of environmental stress.

\section{LITERATURE CITED}

ANGER, K., 1975. On the influence of sewage pollution on inshore benthic communities in the South of Kiel Bay. Part 1. Qualitative studies on indicator species and communities. Merentutkimuslait. Julk. 239, 116-122.

- 1975. The life cycles of the amphipods Batbyporeia sarsi Watkrn, Microdeutopus gryllotalpa Costa and Corophium insidiosum CrawFord in Kiel Bay. Proc. 4th Symposium of the Baltic Marine Biologists, Gdańsk. (In press)

- \& Scheiber, W. Die benthische Copenpodenfauna eines organisch verschmutzten Sandgebietes der westlichen Ostsee. Helgoländer wiss. Meeresunters. 28. (In press)

Erman, D. C. \& Helm, W. T., 1971. Comparison of some species importance values and ordination techniques used to analyse benthic invertebrate communities. Oikos 22, 240-247.

Fonselius, S. H., 1962. Hydrography of the Baltic deep basins. I. Rep. Fishery Bd Sweden, (Hydrography) 13, 5-41.

- 1967. Hydrography of the Baltic deep basins. II. Rep. Fishery Bd Sweden, (Hydrography) 20,3-31.

- 1969. Hydrography of the Baltic deep basins. III. Rep. Fishery Bd Sweden, (Hydrography) 23, 5-93.

GärTNER, H., 1969. Einleitung ungeklärter Abwässer in ein tideloses Meer. Ber. abwassertechn. Vereins 20, 59.

Ghilarov, A. M. \& Timonin, A. G., 1972. Relations between biomass and species diversity in marine and freshwater zooplankton communities. Oikos 23, 190-196.

Gramm, K., 1936. Die Kieler Bucht als Vorfluter für städtische Abwässer. - Bakteriologische Untersuchungen in der Kieler Bucht. Kieler Meeresforsch. 1, 73-124.

GrasshofF, K., 1969. Untersuchungen über die Sauerstoffbestimmung im Meerwasser. IV. Teil. Ober eine Sonde zur digitalen und analogen Registrierung von Sauerstoff, Temperatur und Druck im Meerwasser. Kieler Meeresforsch. 25, 133-142.

Horstmann, U., 1972. Uber den Einfluß von häuslichem Abwasser auf das Plankton in der Kieler Bucht. Kieler Meeresforsch. 28, 178-198.

Hubrich, L. M., 1972. Zur horizontalen Ausbreitung von kontinuierlichen Abflüssen in das küstennahe Meer - am Beispiel einer Abwassereinleitung in die Kieler Bucht. Kieler Meeresforsch. 28, 162-177. 
ICES, 1970. Report of the ICEs Working Group on Pollution of the Baltic Sea. Coop. Res. Rep. (A.) 15, 1-86.

KÄNDLER, R., 1952. Hydrographische Untersuchungen zum Abwasserproblem in den Buchten und Förden der Ostseeküste Schleswig-Holsteins. Kieler Meeresforsch. 9, 177-200.

- 1959. Hydrographische Beobachtungen in der Kieler Förde 1952-1957. Kieler Meeresforsch. $15,145-156$.

- 1960. Typen der Salzgehalts- und Temperaturschichtung in der Kieler Förde. Kieler Meeresforsch. 16, 164-179.

KRUG, J., 1963. Erneuerung des Wassers in der Kieler Bucht im Verlaufe eines Jahres am Beispiel 1960/61. Kieler Meeresforsch. 19, 158-174.

KullenberG, G., 1970. On the oxygen deficit in the Baltic deep water. 7th Conference of the Baltic Oceanographers, Helsinki, May 11-15th. Mimeogr. manuscript.

MacArthur, R. H., 1955. Fluctuations of animal populations and a measure of community stability. Ecology 36, 533-536.

- \& Wuson, E. O., 1967. The theory of island biogeography. Princeton Univ. Press, Princeton, $203 \mathrm{pp}$.

- 1972. Geographical ecology, patterns in the distribution of species. Harper \& Row, New York, 269 pp.

Онг, H., 1959. Temperatur- und Salzgehaltsmessungen an der Oberfläche des Kieler Hafens in den Jahren 1952-1957. Kieler Meeresforsch. 15, 157-160.

PIelou, E. C., 1966a. The measurement of diversity in different types of biological collections. J. theor. Biol. 13, 131-144.

- 1966b. Shannon's formula as a measure of specific diversity: its use and misuse. Am. Nat. $100,463-465$.

- 1969. An introduction to mathematical ecology. Wiley-Interscience, New York, $286 \mathrm{pp}$.

Shannon, C. E. \& WEAVER, W., 1949. The mathematical theory of communication. The University of lllinois Press, Urbana, $117 \mathrm{pp}$.

Simpson, E. H., 1949. Measurement of diversity. Nature, Lond. 163, 688.

Rhernhermer, G., 1966. Einige Beobachtungen über den Einfluß von Ostseewasser auf limnische Bakterienpopulationen. Veröff. Inst. Meeresforsch. Bremerh., (Sonderbd) 2, 237-243.

- 1967. Verschmutzung und Selbstreinigung des Meeres. Christiana Albertina 3, 39-46.

SADJEDI, F., 1971. Qualitative und quantitative Untersuchungen zum Vorkommen der coliformen Bakterien im Bereich der westlichen Ostsee. Diss., Kiel, 120 pp.

Tramer, E. J., 1969. Bird species diversity: components of Shannon's formula. Ecology 50, 927-929.

WATTENBERG, H., 1949. Die Salzgehaltsverteilung in der Kieler Bucht und ihre Abhängigkeit von Strom- und Wetterlage. Kieler Meeresforsch. 6, 17-30.

Author's address: Dr. K. ANGER

Biologische Anstalt Helgoland (Meeresstation)

D-2192 Helgoland

Federal Republic of Germany 